Revista Brasileira de Farmacognosia Brazilian Journal of Pharmacognosy 22(3): 682-713, May/Jun. 2012

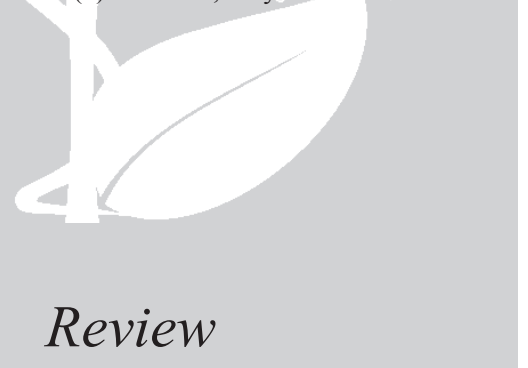

Received 21 Aug 2011

Accepted 16 Dec 2011

Available online 3 Feb 2012

Keywords:

biological activities

chemical constituents

Convolvulaceae

Ipomoea

review

traditional uses

ISSN 0102-695X

http://dx.doi.org/10.1590/S0102-

$695 \mathrm{X} 2012005000025$

\section{Review of the genus Ipomoea: traditional uses, chemistry and biological activities}

\author{
Marilena Meira, ${ }^{*}{ }^{*}$ Eliezer Pereira da Silva, ${ }^{2}$ Jorge M. David, ${ }^{2}$ \\ Juceni P. David
}

\author{
${ }^{I}$ Instituto Federal de Educação, Ciência e Tecnologia da Bahia, Campus Simões \\ Filho, Brazil, \\ ${ }^{2}$ Instituto de Química, Universidade Federal da Bahia, Brazil, \\ ${ }^{3}$ Faculdade de Farmácia, Universidade Federal da Bahia, Brazil.
}

\begin{abstract}
Approximately 600-700 species of Ipomoea, Convolvulaceae, are found throughout tropical and subtropical regions of the world. Several of those species have been used as ornamental plants, food, medicines or in religious ritual. The present work reviews the traditional uses, chemistry and biological activities of Ipomoea species and illustrates the potential of the genus as a source of therapeutic agents. These species are used in different parts of the world for the treatment of several diseases, such as, diabetes, hypertension, dysentery, constipation, fatigue, arthritis, rheumatism, hydrocephaly, meningitis, kidney ailments and inflammations. Some of these species showed antimicrobial, analgesic, spasmolitic, spasmogenic, hypoglycemic, hypotensive, anticoagulant, anti-inflammatory, psychotomimetic and anticancer activities. Alkaloids, phenolics compounds and glycolipids are the most common biologically active constituents from these plant extracts.
\end{abstract}

\section{Introduction}

The Convolvulaceae comprise nearly 1650 predominantly tropical species. The genus Ipomoea, with approximately 500-600 species, comprises the largest number of species within the Convolvulaceae (Austin \& Huáman, 1996). This family is dominated by twining or climbing woody or herbaceous plants that often have heart-shaped leaves and funnel-shaped flowers (Austin, 1997). The genus Ipomoea occurs in the tropics of the world although some species also reach temperate zones (Cao et al., 2005). The species of this genus are mainly distributed throughout the South and Central America countries, and Tropical Africa territories (Austin \& Huáman, 1996). One of the most noticeable anatomical characteristics of the Convolvulaceae is the existence of cells, which secrete resin glycosides in the foliar tissues and in the roots of the plants. These glycoresins constitute one important chemotaxonomic marker of this family (Wagner, 1973) and are responsible for the purgative properties of some species of the Convolvulaceae (Pereda-Miranda $\&$ Bah, 2003). The focus of this review is to provide information on the structures and pharmacological activities of compounds isolated and identified from ipomoea.

\section{Material and Methods}

The pharmacological activities of compounds isolated and identified from Ipomoea were searched through SciFinder that is is one search tools. SciFinder retrieves information in databases produced by Chemical Abstracts Service (CAS) as well as the MEDLINE database of the National Library of Medicine. The CAS databases are: CAplusSM (reference database), REGISTRYSM (chemical structure database), CASREACT ${ }^{\circledR}$ (chemical reaction database), CHEMCATS ${ }^{\circledR}$ (commercial source database), and CHEMLIST $^{\circledR}$ (regulatory database). The data were updated in January 2011, using biological activities or chemical constituents and Ipomoea as keywords.

\section{Results and Discussion}

\section{Traditional uses}

The genus Ipomoea since time immemorial have been in continuous use for different purposes, such as, nutritional, medicinal, ritual and agricultural. The knowledge constitutes a rich source of ethnomedical information for effective selection of plants to be evaluated by chemical studies (Pereda-Miranda \& Bah, 2003). With regard to these nutritional purposes, it is necessary highlight the importance of the I. batatas (L.) Lam. This species originated from Central America, was widely cultivated and consumed almost throughout 
the world (Zhao et al., 2005; Bovell-Benjamin, 2007). I. aquática Forsk is consumed as food in Sri Lanka, Hong Kong, Taiwan e China (Prasad et al., 2005a; Malalavidhane et al., 2000). I aquatica is one of the richest sources of carotenoids and chlorophylls (Wills \& Azhari, 1996). The leaves of I. aquatica contain adequate quantities of most of the essential amino and are comparable to conventional foodstuffs such as soybean or whole egg, indicating the potential of I. aquatica for utilisation as a food supplement. Moreover, the leaves of I. aquatica are an excellent source of bioelements such as calcium, magnesium, iron, zinc, and copper (Rao et al., 1990). Other species consumed for purposes nutritional are $I$. alba L., I. albivenia (Lindl.) Sweet., I. involucrata P. Beauv. and I. leptophylla Torr.

Several species of the genus Ipomoea, as well as, of the Convolvulaceae family have the property of phytotoxicity, which mean suppressing the growth of other plants including invasive weeds. In Mexico, farmers make use of I. tricolor Cav. for this purposes (Bah \& Pereda-Miranda, 1997).

Due to their content of ergot type alkaloids, several species of Ipomoea are used as hallucinogenics. Some of them were used in pre-Columbian times by ancient people to attain a state of mind sutable for divination during religious ceremonies and magical healing practices (Daló \& Moussatché, 1978; Taber et al., 1963). Two species of Ipomoea are detached in the entheogen use. They are I. corymbosa (Rivea corymbosa) and I. violaceae L. The seeds these Ipomoea were known respectively as "ololiuhqui" and tlitliltzin in Aztecs lingua and they are still used even today by certain natives in Mexico (Halpern, 2004; Daló \&
Moussatché, 1978). Today, the ritual incorporates many elements from Catholic religion, including the names given to the plants, such as, "Seeds of the Virgin", Holy Mary Herb" and "Virgin's Cloak". Demontrating the syncretism with the Christian traditions and that for natives Ipomoea species are gift from the gods (Pereda-Miranda \& Bah, 2003). To the resemblance of the natives in Mexico, still today, in the candomble, the "father of saint" also uses seeds and leaves of Ipomoea species, such as, I. alba, I. pes-caprae and I. purpurea in the preparations that are offered to the adept of the religion, to attain a state of mind sutable for divination in the ceremonial religious (Camargo, 1998).

Various species of Ipomoea have been used extensively, in many countries, in the traditional medicine for the treatment of several diseases (Chater 1). The most common use of the roots of Ipomoea species is to treat constipation (Pereda-Miranda \& Bah, 2003).

\section{Chemistry and biological activities}

The phytochemistry of the Ipomoea genus has been studied since 1950. Some species of Ipomoea showed antimicrobial, analgesic, spasmolitic, spasmogenic, hypotensive, psychotomimetic and anticancer activities. The most common biologically active constituents from these plants (Chart 2) are ergoline alkaloids (1-12), indolizidine alkaloids (13-15), nortropane alkaloids (1619), phenolics compounds (20-32), coumarins (33-36) norisoprenoids, diterpene, isocoumarin and benzenoids (37-43) flavonoids and antocianosides (44-56), glycolipids (57-102), lignan (103) and triterpenes (104-110).

Charter 1. Traditional uses of Ipomoea species.

\begin{tabular}{|c|c|}
\hline Species & Traditional uses \\
\hline I. aquatica & $\begin{array}{l}\text { Treatment of diabetes (indigenous medicine in Sri Lanka) (Jayaweera, 1982; Malalavidhane et al., 2001). Scorpion } \\
\text { venom antidote (Uawonggul, et al., 2006), as emetic, diuretic, purgative, to treating debility, liver complaints, } \\
\text { ringworm, leucoderma, leprosy, fever (Ghani, 1989; Mamun, et al., 2003), against nosebleed and high blood } \\
\text { pressure (Prasad et al., 2005a). }\end{array}$ \\
\hline I. asarifolia & Against itch (Silva, 2002). \\
\hline I. batatas & $\begin{array}{l}\text { Treatment of tumors of the mouth and throat. Leaves decoctions are used as alterative, aphrodisiac, astringent, } \\
\text { bactericide, demulcent, fungicide, laxative and tonic. Sweetpotato is used to treating asthma, bugbites, burns, } \\
\text { catarrh, ciguatera, convalescence, diarrhea, dyslactea, fever, nausea, renosis, splenosis, stomach distress, tumors, } \\
\text { and whitlows (Duke \& Wain, 1981). In region of Kagawa, Japan, a variety of white sweet potato has been eaten } \\
\text { raw to treating anemia, hypertension and diabetes (Ludvik et al., 2004). }\end{array}$ \\
\hline I. cairica & Treatment of rheumatism and inflammations (Ferreira et al., 2006). \\
\hline $\begin{array}{l}\text { I } \\
\text { campanulata }\end{array}$ & Antidote to snake poison (Singh et al., 2003). \\
\hline I. carnea & $\begin{array}{l}\text { Against Immunodeficiency Syndrome (AIDS) (Thailand) (Woradulayapinij et al., 2005) and to treat hypertension } \\
\text { (Gabon) (Lamidi et al., 2000). }\end{array}$ \\
\hline I. digitata & $\begin{array}{l}\text { The powdered root is used in emaciation of children and also as tonic, alterative, aphrodisiac, demulcent, } \\
\text { lactogogue, and cholagogue. Decoctions of root against constipation (Singh et al., 2004). }\end{array}$ \\
\hline
\end{tabular}




\begin{tabular}{|c|c|}
\hline I. indica & As purgative and healing broken bones (Hawaii) (Abbott \& Shimazu, 1985). \\
\hline I. leptophylla & $\begin{array}{l}\text { The smoke of burneed the roots in treatment of nervousness (Native Americans Pawnee) (Gilmore, 1977). The } \\
\text { root for stomach distress (Lakota people) and tonic (early European settlers) (Barnes et al., 2003). }\end{array}$ \\
\hline I. muricata & $\begin{array}{l}\text { To treating several types of skin ailments such as chronic and gangrenous wounds, cuts and blisters due to burns } \\
\text { (Philippines). Glycerol preparations of the crude drug of I. muricata are used for the treatment of pharyngitis and } \\
\text { an otic preparation for the treatment of otitis externa (Ysrael, 2003). }\end{array}$ \\
\hline I. murucoides & $\begin{array}{l}\text { The smoke from the burned tree is used against mosquitoes (Mexico). Infusions of the leaves, bark and flowers to } \\
\text { treat inflamations and against scorpion bites (León et al., 2005). }\end{array}$ \\
\hline I. nil & Treatments against cancer (East Asia) (Ko et al., 2004). \\
\hline I. orizabensis & $\begin{array}{l}\text { As purgative (American and European pharmacopeas) (Pereda-Miranda, 1995), anthelmintic and to treat abdominal } \\
\text { fever, dysentery, epilepsy, hydrocephaly, meningitis and tumors (Martinez, 1990). }\end{array}$ \\
\hline I. pes-caprae & $\begin{array}{l}\text { Treatment of inflammatory and algesic processes (Souza et al., 2000). Heated leaves are used to treating wound, } \\
\text { skin infections, inflamed sores and stings from poisonous fish, manta-ray and insects (Australian) (Infusions have } \\
\text { been recommended for treating hypertension, kidney ailments and decoctions to treat digestive disorders, colic, } \\
\text { internal and external pain, dysentery, inflammations, fatigue, strain, arthritis and rheumatism. The roots are used } \\
\text { in diuretic disorders and in constipation (Pereda-Miranda et al., 2005; Lorenzi \& Abreu Matos, 2002; Diaz, 1976; } \\
\text { Martinez, 1989). }\end{array}$ \\
\hline I. purga & As purgative (Pereda-Miranda \& Bah, 2003). \\
\hline I. purpurea & $\begin{array}{l}\text { Infusions are used as diuretic, to stop hemorrhage (Bolivia), as purgative and to treat syphilis (Africa) (Camargo, } \\
\text { 1998). }\end{array}$ \\
\hline I. stans & $\begin{array}{l}\text { Infusions of the roots have been used for treating epileptic seizures (Mexico), nephrits, ophthalmic diseases and } \\
\text { paralysis, as antiespasmodic and sedative agent (Diaz, 1976). As purgative (Pereda-Miranda \& Bah, 2003). }\end{array}$ \\
\hline I. stolonifera & $\begin{array}{l}\text { As diuretic and to treat pain after childbirth, stomach problems, inflamations, furunculosis, swelling and wound } \\
\text { (Paula et al., 2003). }\end{array}$ \\
\hline
\end{tabular}

Chart 2. Bioactive compounds from the genus Ipomoea.

\begin{tabular}{|c|c|c|}
\hline Substances & Species & Activities \\
\hline \multicolumn{3}{|l|}{ Ergoline alkaloids } \\
\hline Agroclavine (1) & $\begin{array}{l}\text { I. fistulosa } \\
\text { I. mueller } \\
\text { I. tricolor }\end{array}$ & $\begin{array}{l}\text { Antimicrobial } \\
\text { Cytostatic }\end{array}$ \\
\hline hanoclavine I (2) & $\begin{array}{l}\text { I. asarifolia } \\
\text { I. hederacea } \\
\text { I. muelleri } \\
\text { I. corymbosa } \\
\text { I. tricolor } \\
\text { I. violacea }\end{array}$ & $\begin{array}{l}\text { Psychotropic } \\
\text { Psychotomimetic }\end{array}$ \\
\hline elymoclavine (3) & $\begin{array}{l}\text { I. hederacea } \\
\text { I. muelleri } \\
\text { I. corymbosa } \\
\text { I. parasitica } \\
\text { I. violacea }\end{array}$ & $\begin{array}{l}\text { Psychotropic } \\
\text { Psychotomimetic }\end{array}$ \\
\hline ergine (LSA) (4) & $\begin{array}{l}\text { I. asarifolia } \\
\text { I. muelleri } \\
\text { I. corymbosa } \\
\text { I. tricolor } \\
\text { I. violacea }\end{array}$ & $\begin{array}{l}\text { Psychotropic } \\
\text { Psychotomimetic }\end{array}$ \\
\hline erginine (5) & $\begin{array}{l}\text { I. muelleri } \\
\text { I. corymbosa } \\
\text { I. tricolor } \\
\text { I. violacea }\end{array}$ & $\begin{array}{l}\text { Psychotropic } \\
\text { Psychotomimetic }\end{array}$ \\
\hline $\begin{array}{l}\text { ergocristine (6) } \\
\text { ergotamine (7) }\end{array}$ & I. tricolor & $\begin{array}{l}\text { Psychotropic } \\
\text { Psychotomimetic }\end{array}$ \\
\hline
\end{tabular}




\begin{tabular}{|c|c|c|}
\hline ergometrine or ergonovine (8) & $\begin{array}{l}\text { I. muelleri } \\
\text { I. corymbosa } \\
\text { I. tricolor } \\
\text { I. violacea }\end{array}$ & $\begin{array}{l}\text { Psychotropic } \\
\text { Psychotomimetic } \\
\text { Vasoconstrictor } \\
\text { Hemostatic } \\
\text { Uterotonic } \\
\end{array}$ \\
\hline ergosinine (9) & I. palmata & Uterotonic \\
\hline festuclavine (10) & I. muelleri & Antimicrobial \\
\hline lysergol (11) & $\begin{array}{l}\text { I. hederacea } \\
\text { I. muelleri } \\
\text { I. parasitica } \\
\text { I. petaloidea } \\
\text { I. corymbosa } \\
\text { I. violacea }\end{array}$ & $\begin{array}{l}\text { Psychotropic } \\
\text { Psychotomimetic }\end{array}$ \\
\hline penniclavine (12) & $\begin{array}{l}\text { I. hederacea } \\
\text { I. muelleri } \\
\text { I. corymbosa } \\
\text { I. violacea }\end{array}$ & Psychotropic \\
\hline
\end{tabular}<smiles>CC1=C[C@H]2c3cccc4[nH]cc(c34)C[C@]2(C)N(C)C1</smiles>

1<smiles>C/C(=C\[C@@H]1c2cccc3[nH]cc(c23)C[C@@H]1N(C)C)CO</smiles>

2<smiles>CN1CC(CO)=CC2c3cccc4[nH]cc(c34)C[C@H]21</smiles>

3<smiles>CN1C[C@H](C(N)=O)C=C2c3cccc4[nH]cc(c34)C[C@H]21</smiles>

4<smiles>CN1C[C@H](C(N)=O)C=C2c3cccc4[nH]cc(c34)C[C@]21C</smiles>

5<smiles>[R]C1(NC(=O)[C@@H]2C=C3c4cccc5[nH]cc(c45)C[C@]3(C)N(C)C2)OC2N(C1=O)[C@@H](Cc1ccccc1)C(=O)N1CCC[C@]21C</smiles>

$6 \mathrm{R}=\mathrm{CH}(\mathrm{Me})_{2}$ $7 \mathrm{R}=\mathrm{Me}$<smiles>C[C@H]1CC2c3cccc4[nH]cc(c34)C[C@H]2N(C)C1</smiles>

10<smiles>C[C@H](CO)NC(=O)[C@@H]1C=C2c3cccc4[nH]cc(c34)C[C@H]2N(C)C1</smiles>

8<smiles>CN1C[C@H](CO)C=C2c3cccc4[nH]cc(c34)C[C@H]21</smiles>

11<smiles>CC(C)C[C@H]1C(=O)N2CCC[C@]2(O)C2(O)O[C@](C)(NC(=O)[C@@H]3C=C4c5cccc6[nH]cc(c56)C[C@]4(C)N3C)C(=O)N12</smiles>

9<smiles>CN1C[C@H](O)C=C2c3cccc4[nH]cc(c34)C[C@H]21</smiles>

12 
Review of the genus Ipomoea: traditional uses, chemistry and biological activities

Marilena Meira et al.

\begin{tabular}{|lll|}
\hline Indolizidine alkaloids & & \\
\hline ipalbidine (13) & $\begin{array}{l}\text { I. alba } \\
\text { I. muricata } \\
\text { I. hardwickki }\end{array}$ & Analgesic \\
& Antioxidant \\
\hline 2-epi-lentiginosine (14) & I. carnea & $\begin{array}{l}\text { Potent inhibitory activitytoward rat } \\
\alpha \text {-mannosidase }\end{array}$ \\
\hline swainsonine (15) & I. carnea & $\begin{array}{l}\text { Immunomodulatory Antimetastatic } \\
\text { Potent inhibitory activity toward rat } \\
\end{array}$ \\
& & $\alpha$-mannosidase \\
\hline
\end{tabular}<smiles>CC1=C(c2ccc(O)cc2)CN2CCC[C@H]2C1</smiles>

13<smiles>O[C@H]1CN2CCCCC2[C@H]1O</smiles>

14<smiles>O[C@H]1CN2CCC[C@H](O)[C@H]2[C@@H]1O</smiles>

15

\begin{tabular}{|c|c|c|}
\hline \multicolumn{3}{|l|}{ Nortropane alkaloids } \\
\hline $\begin{array}{l}\text { calystegine B1 (16) } \\
\text { calystegine B2 (17) } \\
\text { calystegine C1 (18) }\end{array}$ & $\begin{array}{l}\text { I. alba } \\
\text { I. aquatica } \\
\text { I. batatas } \\
\text { I. carnea } \\
\text { I. hederifolia } \\
\text { I. eremnobrocha } \\
\text { I. obscura } \\
\text { I. pes-caprae } \\
\text { I. setifera } \\
\text { I. violacea }\end{array}$ & $\begin{array}{l}\text { Potent inhibitory activity toward rat } \\
\text { lysosomal } \beta \text {-glucosidase. }\end{array}$ \\
\hline calystegine B3 (19) & $\begin{array}{l}\text { I. alba } \\
\text { I. aquatica } \\
\text { I. batatas } \\
\text { I. carnea } \\
\text { I. hederifolia } \\
\text { I. eremnobrocha } \\
\text { I. obscura } \\
\text { I. pes-caprae } \\
\text { I. setifera } \\
\text { I. violacea }\end{array}$ & $\begin{array}{l}\text { Moderate inhibitory activity toward rat } \\
\alpha \text { - and } \beta \text {-mannosidases }\end{array}$ \\
\hline \multicolumn{3}{|l|}{ Phenolics compounds } \\
\hline $\begin{array}{l}N \text {-cis-feruloyl tyramine }(\mathbf{2 0}) \\
\text { 21: } N \text {-trans-feruloyl tyramine (21) }\end{array}$ & I. aquatica & Inhibition of prostaglandin synthesis \\
\hline cafeic acid (22) & $\begin{array}{l}\text { I. batatas } \\
\text { I. muricata }\end{array}$ & $\begin{array}{l}\text { Antioxidant } \\
\text { Antimutagenic }\end{array}$ \\
\hline $\begin{array}{l}\text { 3-O-caffeoyl-quinic acid } \\
\text { (clorogenic acid) }(\mathbf{2 3})\end{array}$ & $\begin{array}{l}\text { I. batatas } \\
\text { I. fistulosa }\end{array}$ & $\begin{array}{l}\text { Hypoglycemic, antimutagenic } \\
\text { antioxidant and inhibition of HIV } \\
\text { replication }\end{array}$ \\
\hline $\begin{array}{l}\text { 3,5-di- } O \text {-caffeoyl-quinic acid (24) } \\
\text { (isoclorogenic acid a) }\end{array}$ & $\begin{array}{l}\text { I. aquatica } \\
\text { I. batatas } \\
\text { I. pes-caprae } \\
\text { I. fistulosa }\end{array}$ & $\begin{array}{l}\text { Hypoglycemic, antimutagenic } \\
\text { antioxidant and inhibition of HIV } \\
\text { replication. } \\
\text { Antifungal, antispasmodic } \\
\text { Collagenase inhibitory }\end{array}$ \\
\hline
\end{tabular}




\begin{tabular}{|c|c|c|}
\hline $\begin{array}{l}\text { 3,4-di- } O \text {-caffeoyl-quinic acid (25) } \\
\text { (isoclorogenic acid b) }\end{array}$ & $\begin{array}{l}\text { I. aquatica } \\
\text { I. batatas } \\
\text { I. pes-caprae }\end{array}$ & $\begin{array}{l}\text { Hypoglycemic, antimutagenic } \\
\text { antioxidant and inhibition of HIV } \\
\text { replication. } \\
\text { Collagenase inhibitory }\end{array}$ \\
\hline $\begin{array}{l}\text { 4,5-di- } O \text {-caffeoyl-quinic acid (26) } \\
\text { (isoclorogenic acid c) }\end{array}$ & $\begin{array}{l}\text { I. aquatica } \\
\text { I. batatas } \\
\text { I. pes-caprae } \\
\text { I. fistulosa }\end{array}$ & $\begin{array}{l}\text { Hypoglycemic, antimutagenic } \\
\text { antioxidant and inhibition of HIV } \\
\text { replication. } \\
\text { Collagenase inhibitory }\end{array}$ \\
\hline 3,4,5-tri- $O$-caffeoyl-quinic acid (27) & I. batatas & $\begin{array}{l}\text { Hypoglycemic, antimutagenic } \\
\text { Antioxidant and inhibition of HIV } \\
\text { replication }\end{array}$ \\
\hline $\begin{array}{l}\text { 3,5-di- } O \text {-caffeoyl-4- } O \text {-coumaroyl-quinic } \\
\text { acid (28) } \\
\text { 4,5-di- } O \text {-caffeoyl-1,3-di- } O \text {-coumaroyl- } \\
\text { quinic acid (29) } \\
4,5 \text {-di- } O \text {-caffeoyl-quinic acid methyl } \\
\text { ester }(\mathbf{3 0}) \\
\text { 3,4-di- } O \text {-caffeoyl-quinic acid methyl } \\
\text { ester }(\mathbf{3 1}) \\
\text { 3,5-di- } O \text {-caffeoyl-quinic acid methyl } \\
\text { ester }(\mathbf{3 2})\end{array}$ & I. pes-caprae & Collagenase inhibitory \\
\hline
\end{tabular}<smiles>[R]C1C2CC(O)(O)C(N2)C([R])C(O)C1O</smiles>

$16 \mathrm{R}=\mathrm{H} ; \mathrm{R}_{1}=\mathrm{OH}$

$17 \mathrm{R}=\mathrm{OH} ; \mathrm{R}_{1}=\mathrm{H}$

$18 \mathrm{R}=\mathrm{R}_{1}=\mathrm{OH}$<smiles>OC1CCC2NC1C(O)C2O</smiles>

19<smiles>COc1cc(/C=C/C(=O)NCCc2ccc(O)cc2)ccc1O</smiles>

20<smiles>COc1cc(/C=C/C(=O)NCCc2ccc(O)cc2)ccc1O</smiles>

21<smiles>O=C(O)/C=C/c1ccc(O)c(O)c1</smiles>

22

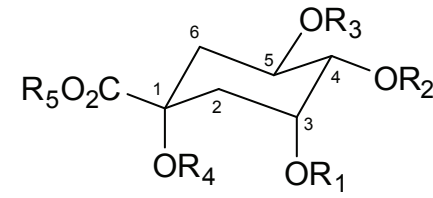

$23 \mathrm{R}_{1}=$ caffeoyl; $\mathrm{R}_{2}=\mathrm{R}_{3}=\mathrm{R}_{4}=\mathrm{R}_{5}=\mathrm{H}$

$24 \mathrm{R}_{1}=\mathrm{R}_{3}=$ caffeoyl; $\mathrm{R}_{2}=\mathrm{R}_{4}=\mathrm{R}_{5}=\mathrm{H}$

$25 R_{1}=R_{2}=$ caffeoyl; $R_{3}=R_{4}=R_{5}=H$

$26 R_{2}=R_{3}=$ caffeoyl, $R_{1}=R_{4}=R_{5}=H$

$27 \mathrm{R}_{1}=\mathrm{R}_{2}=\mathrm{R}_{3}=$ caffeoyl; $\mathrm{R}_{4}=\mathrm{R}_{5}=\mathrm{H}$

$28 \mathrm{R}_{1}=\mathrm{R}_{3}=$ caffeoyl; $\mathrm{R}_{2}=$ coumaroyl; $\mathrm{R}_{4}=\mathrm{R}_{5}=\mathrm{H}$

$29 \mathrm{R}_{1}=\mathrm{R}_{4}=$ coumaroyl; $\mathrm{R}_{2}=\mathrm{R}_{3}=$ caffeoyl; $\mathrm{R}_{5}=\mathrm{H}$

$30 \mathrm{R}_{1}=\mathrm{R}_{4}=\mathrm{H} ; \mathrm{R}_{2}=\mathrm{R}_{3}=$ caffeoyl; $\mathrm{R}_{5}=\mathrm{Me}$

$31 \mathrm{R}_{1}=\mathrm{R}_{2}=$ caffeoyl; $\mathrm{R}_{3}=\mathrm{R}_{4}=\mathrm{H} ; \mathrm{R}_{5}=\mathrm{Me}$

$32 \mathrm{R}_{1}=\mathrm{R}_{3}=$ caffeoyl; $\mathrm{R}_{2}=\mathrm{R}_{4}=\mathrm{H} ; \mathrm{R}_{5}=\mathrm{Me}$ 
Review of the genus Ipomoea: traditional uses, chemistry and biological activities

Marilena Meira et al.

\begin{tabular}{|lll|}
\hline Coumarins & & \\
\hline coumarin $\mathbf{( 3 3 )}$ & I. turpethum & $\begin{array}{l}\text { Cytotoxic, immunostimulant and } \\
\text { antiedema }\end{array}$ \\
\hline scopoletin (34) & I. batatas & Hepatoprotective \\
& I. cairica & Spasmolytic \\
& I. digitata & Inhibition of prostate cancer proliferation \\
& I stans & Acetylcholinesterase inhibitory \\
& I. turpethum & Antioxidant \\
& & Anticoagulant \\
\hline esculetin $(\mathbf{3 5})$ & I. batatas & Anti-HIV \\
\hline umbelliferon $\mathbf{( 3 6 )}$ & & Antioxidant \\
& I. batatas & Anticoagulant \\
& I. cairica & Anti-HIV \\
\hline I. digitata & Anticoagulant \\
\hline
\end{tabular}<smiles>[R]c1cc2ccc(=O)oc2cc1[R]</smiles>

\section{$33 \mathrm{R}_{1}=\mathrm{R}_{2}=\mathrm{H}$ \\ $34 \mathrm{R}_{1}=\mathrm{OH} ; \mathrm{R}_{2}=\mathrm{OMe}$ \\ $35 \mathrm{R}_{1}=\mathrm{R}_{2}=\mathrm{OH}$ \\ $36 \mathrm{R}_{1}=\mathrm{OH} ; \mathrm{R}_{2}=\mathrm{H}$}

\begin{tabular}{|c|c|c|}
\hline \multicolumn{3}{|c|}{ Norisoprenoids, diterpene, isocoumarin and benzenoids } \\
\hline actinidol (37) & I. pes-caprae & $\begin{array}{l}\text { Inhibition of ethyl phenylpropiolate- } \\
\text { induced rat ear oedema }\end{array}$ \\
\hline $\begin{array}{l}\text { trans- } \beta \text {-damascenone (38) } \\
\text { E-phytol (39) }\end{array}$ & I. pes-caprae & Antispasmodic activity \\
\hline $\begin{array}{l}\text { 3,4-dihydro-8-hydroxi-3- } \\
\text { methylisocoumarin (40) eugenol (41) } \\
\text { 4,4,7-trimethyl-1,4-dihydro-2-hydroxy- } \\
\text { 1-naftalenone (42) 4-vinyl-guaiacol (43) }\end{array}$ & I. pes-caprae & Inhibition of prostaglandin synthesis \\
\hline \multicolumn{3}{|l|}{ Flavonoids and antocianosides } \\
\hline $\begin{array}{l}3 \alpha, 7 \beta-O \text {-D-diglycopyranosyl- } \\
\text { dihydroquercetin }(\mathbf{4 4})\end{array}$ & I. aquatica & Antioxidant; cytotoxic, in vitro. \\
\hline peonidin (45) & I. batatas & Antioxidant \\
\hline $\begin{array}{l}\text { 3-O-(2-O-(6-O-E-caffeoyl- } \beta \text {-D- } \\
\text { glycopyranosyl))-(6-O-E-caffeoyl)- } \\
\beta \text {-D-glycopyranosyl)-5-O- } \beta \text {-D- } \\
\text { glycopyranoside-cianidin }(46)\end{array}$ & $\begin{array}{l}\text { I. asarifolia } \\
\text { I. batatas } \\
\text { I. purpurea }\end{array}$ & Antioxidant \\
\hline $\begin{array}{l}\text { 3-O-Sophoroside-5-O-glycosil-cianidin } \\
\text { (47) }\end{array}$ & I. batatas & Antimutagenic \\
\hline $\begin{array}{l}\text { 3-O-(6-O-trans-caffeoyl-2-O- } \beta \text { - } \\
\text { glycopyranosyl- } \beta \text {-glycopyranoside)-5-O- } \\
\beta \text {-glycoside-cianidin (48) } \\
\text { 3-O-(6-O-trans-caffeoyl-2- } O-\beta \\
\text {-glycopyranosyl- } \beta \text {-glycopyranoside)-5- } \\
O \text { - } \beta \text {-glucoside-peonidin (49) }\end{array}$ & I. batatas & Antioxidant \\
\hline
\end{tabular}


3-O-(2-O-(6-O-p-hydroxybenzoil- $\beta$ -

D-glucopyranosyl))-(6-O-E-caffeoyl)-

$\beta$-D-glucopyranosyl)-5- $O-\beta$-D-

glycopyranoside-cianidin $(\mathbf{5 0})$

3-O-(2-O-(6-O-E-feruloyl- $\beta$-Dglycopyranosyl))-(6-O-E-caffeoyl)-

$\beta$ - $D$-glycopyranosyl)-5- $O-\beta$-D-

glycopyranoside-cianidin (51)

$3-O-(2-O-(6-O-E$-caffeoyl- $\beta-\mathrm{D}-$ glycopyranosyl))-(6-O-E-caffeoyl)-

$\beta$-D-glycopyranosyl)-5- $O$ - $\beta$-D-

glycopyranoside-peonidin (52)

3-O-(2-O-(6-O-p-hydroxybenzoil- $\beta$ -

D-glycopyranosyl))-(6-O-E-caffeoyl)-

$\beta$-D-glycopyranosyl)-5-O- $\beta$-D-

glycopyranoside-peonidin (53)

3-O-(2-O-(6-O-E-feruloyl- $\beta$-D-

glycopyranosyl))-(6-O-E-caffeoyl)-

$\beta$-D-glycopyranosyl)-5- $O$ - $\beta$-D-

glycopyranoside-peonidin (54)

$3-O-\beta$-D-glycofuranosyl quercetin (55)

heavenly blue anthocyanin (56)
I. batatas

I. batatas

Antimutagenic
Antioxidant

Antioxidant

Antioxidant
Antimutagenic

I. batatas

Antioxidant<smiles>CC(O)C1C=C2C(C)(C)CC=CC2(C)O1</smiles>

37<smiles>C[C@H]1Cc2cccc(O)c2C(=O)O1</smiles>

40<smiles>C/C=C/C(=O)C1=C(C)C=CCC1(C)C</smiles>

38<smiles>Cc1ccc2c(c1)C(=O)C(O)=CC2(C)C</smiles>

42
Antioxidant Antimutagenic

Anti- hyperglycemic<smiles>C/C(=C\CO)CCC[C@H](C)CCC[C@H](C)CCCC(C)C</smiles>

39

Antinociceptive

I. tricolor Protection against UV-B radiation<smiles>O=C1c2c(O)cccc2OC(c2ccc(O)c(O)c2)C1OC1OC(CO)C(O)C(O)C1O</smiles>

44<smiles>COc1cc(C(=O)C(O)=Cc2c(O)cc(O)cc2O)ccc1O</smiles>

45 


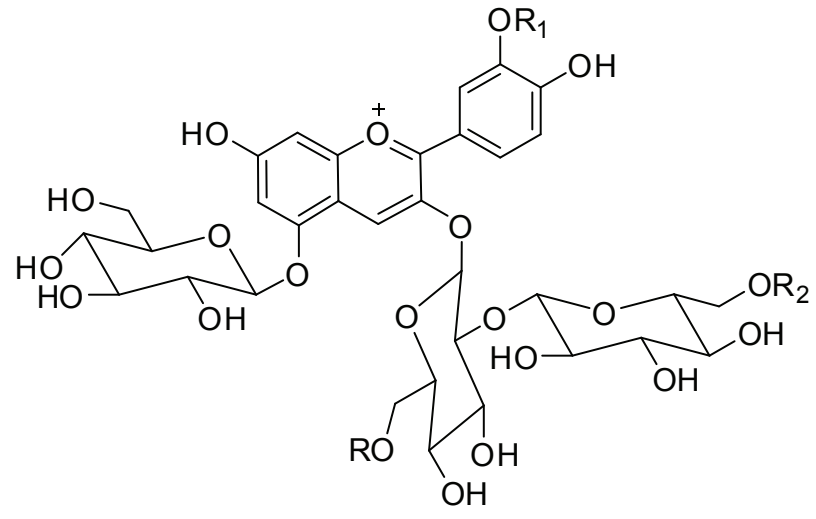

$46 \mathrm{R}=\mathrm{R}_{2}=$ caffeoyl; $\mathrm{R}_{1}=\mathrm{H}$

$47 \mathrm{R}=\mathrm{R}_{1}=\mathrm{R}_{2}=\mathrm{H}$

$48 \mathrm{R}=$ caffeoyl; $\mathrm{R}_{1}=\mathrm{R}_{2}=\mathrm{H}$

$49 \mathrm{R}=$ caffeoyl; $\mathrm{R}_{1}=\mathrm{Me} ; \mathrm{R}_{2}=\mathrm{H}$

$50 \mathrm{R}=$ caffeoyl; $\mathrm{R}_{1}=\mathrm{H} ; \mathrm{R}_{2}=p$-hydroxy-benzoyl

$51 \mathrm{R}=\mathrm{R}_{2}=$ caffeoyl; $\mathrm{R}_{1}=\mathrm{Me}$

$52 \mathrm{R}=$ caffeoyl; $\mathrm{R}_{1}=\mathrm{H} ; \mathrm{R}_{2}=p$-hydroxy-benzoyl

$53 \mathrm{R}=$ caffeoyl; $\mathrm{R}_{1}=\mathrm{Me} ; \mathrm{R}_{2}=p$-hydroxy-benzoyl

$54 \mathrm{R}=$ caffeoyl; $\mathrm{R}_{1}=$ Me; $\mathrm{R}_{2}=$ feruloyl<smiles>O=c1c(OC2OC([C@H](O)CO)[C@@H](O)[C@H]2O)c(-c2ccc(O)c(O)c2)oc2cc(O)cc(O)c12</smiles>

55

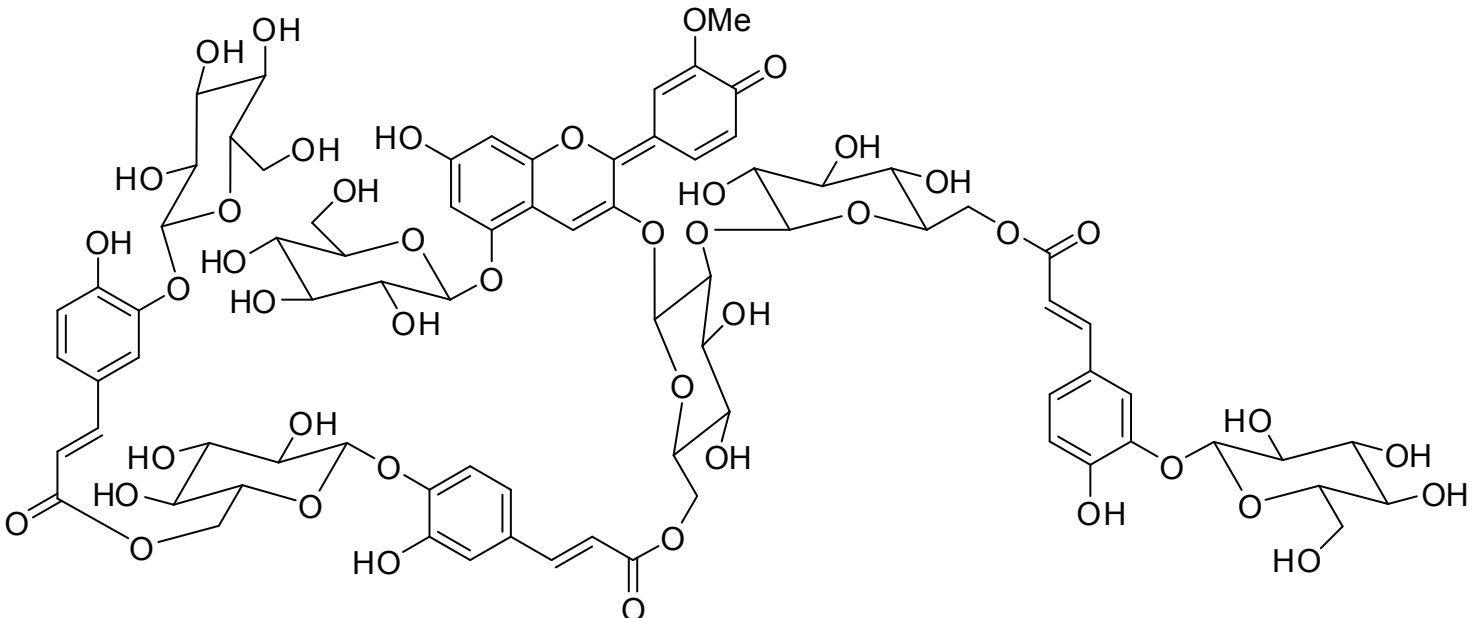

56

\begin{tabular}{|lll|}
\hline Glycolipids & & \\
\hline scammonine I $\mathbf{( 5 7 )}$ & I. orizabensis & $\begin{array}{l}\text { Weak cytotoxicity against oral human } \\
\text { epidermal carcinoma. Against methicillin- } \\
\text { resistant staphylococcal }\end{array}$ \\
\hline scammonine II (58) & I. orizabensis & $\begin{array}{l}\text { Weak cytotoxicity against oral human } \\
\text { epidermal carcinoma, }\end{array}$ \\
\hline ipomoeassins A-E $\mathbf{( 5 9 - 6 3 )}$ & I. squamosa & Cytotoxic against ovarian carcinoma \\
\hline murucin 1 $(\mathbf{6 4})$ & I. murucoides & Cytotoxic against ovarian carcinoma \\
\hline orizabins I-IV $(\mathbf{6 5 - 6 8})$ & I. orizabensis & Laxative \\
\hline orizabins V-VII $(\mathbf{6 9 - 7 1 )}$ & I. orizabensis & $\begin{array}{l}\text { Weak cytotoxicity against oral human } \\
\text { epidermal carcinoma }\end{array}$ \\
\hline
\end{tabular}




\begin{tabular}{|c|c|c|}
\hline orizabins IX-XXI (72-84) & I. orizabensis & $\begin{array}{l}\text { Cytotoxicity against oral epidermoid } \\
\text { carcinoma but weak cytotoxicity against } \\
\text { colon carcinoma, squamoux cell cervix } \\
\text { carcinoma and ovarium cancer }\end{array}$ \\
\hline orizabin VIII (85) & I. orizabensis & $\begin{array}{l}\text { Weak cytotoxicity against colon } \\
\text { carcinoma. }\end{array}$ \\
\hline $\begin{array}{l}\text { pescaproside A }(\mathbf{8 6}) \\
\text { pescapreins I-IV }(\mathbf{8 7 - 9 0})\end{array}$ & I. pes-caprae & $\begin{array}{l}\text { Weak cytotoxicity against nasopharyngeal, } \\
\text { colon, squamous cell cervical and ovarian } \\
\text { carcinomas }\end{array}$ \\
\hline simonin IV (91) & I. batatas & Fitotoxicity \\
\hline stansin $5(92)$ & I. stans & $\begin{array}{l}\text { Cytotoxicity against cervical and ovarian } \\
\text { carcinomas }\end{array}$ \\
\hline tricolorin A (93) & I. tricolor & $\begin{array}{l}\text { Fitotoxicity; Cytotoxic against breast } \\
\text { carcinoma; Cytotoxicity against oral } \\
\text { epidermoid carcinoma and weak } \\
\text { cytotoxicity against colon, cervical and } \\
\text { ovarian carcinomas } \\
\text { Antibacteriana against Staphylococcus } \\
\text { aureus }\end{array}$ \\
\hline tricolorin B (94) & I. tricolor & $\begin{array}{l}\text { Cytotoxicity against oral epidermoid } \\
\text { carcinoma and weak cytotoxicity against } \\
\text { colon, cervical and ovarian carcinomas. } \\
\text { Antibacteriana against Staphylococcus } \\
\text { aureus. }\end{array}$ \\
\hline $\begin{array}{l}\text { tricolorins C e E }(\mathbf{9 5}, \mathbf{9 6}) \\
\text { tricolorins D, F-J }(\mathbf{9 7 - 1 0 2 )}\end{array}$ & I. tricolor & $\begin{array}{l}\text { Cytotoxicity against oral epidermoid } \\
\text { carcinoma and weak cytotoxicity against } \\
\text { colon, cervical and ovarian carcinomas. }\end{array}$ \\
\hline
\end{tabular}

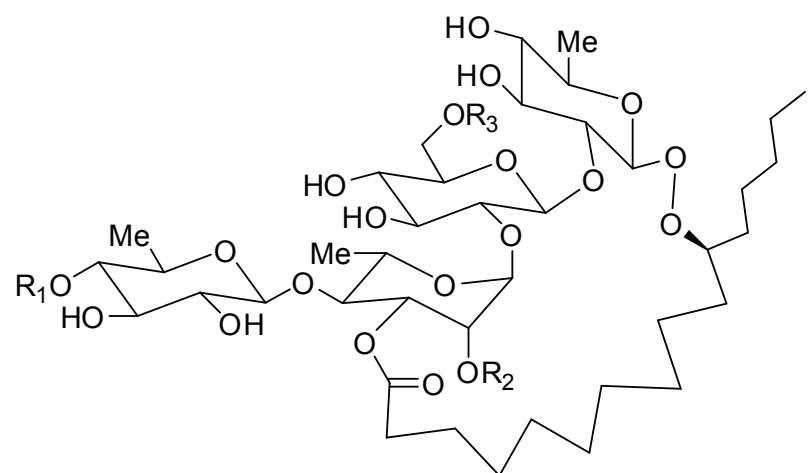<smiles></smiles><smiles>[B-]C=CC(C)C=O</smiles>

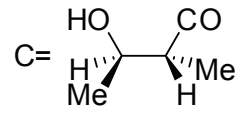

$57 \mathrm{R}_{1}=\mathrm{A} ; \mathrm{R}_{2}=\mathrm{B} ; \mathrm{R}_{3}=\mathrm{H}$ $58 \mathrm{R}_{1}=\mathrm{H} ; \mathrm{R}_{2}=\mathrm{B} ; \mathrm{R}_{3}=\mathrm{H}$

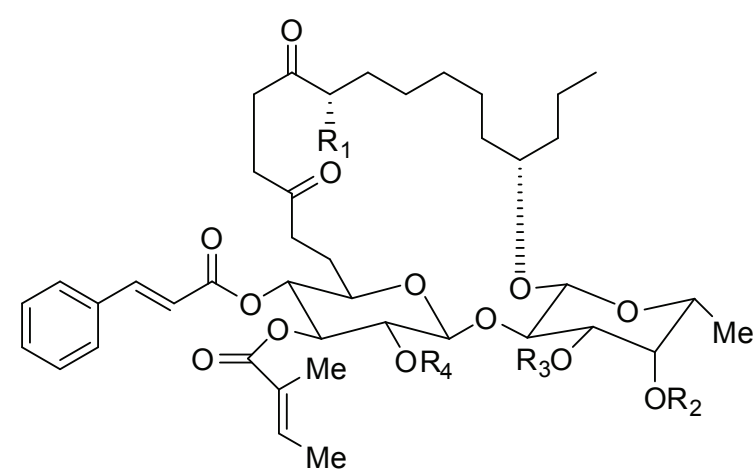

$59 \mathrm{R}_{1}=\mathrm{R}_{3}=\mathrm{R}_{4}=\mathrm{H} ; \mathrm{R}_{2}=\mathrm{Ac}$

$60 \mathrm{R}_{1}=\mathrm{R}_{2}=\mathrm{R}_{3}=\mathrm{R}_{4}=\mathrm{H}$

$61 \mathrm{R}_{1}=\mathrm{OH} ; \mathrm{R}_{2}=\mathrm{Ac} ; \mathrm{R}_{3}=\mathrm{R}_{4}=\mathrm{H}$

$62 \mathrm{R}_{1}=\mathrm{OAc} ; \mathrm{R}_{2}=\mathrm{Ac} ; \mathrm{R}_{3}=\mathrm{R}_{4}=\mathrm{H}$

$63 \mathrm{R}_{1}=\mathrm{OAc} ; \mathrm{R}_{2}=\mathrm{R}_{3}=\mathrm{R}_{4}=\mathrm{H}$ 


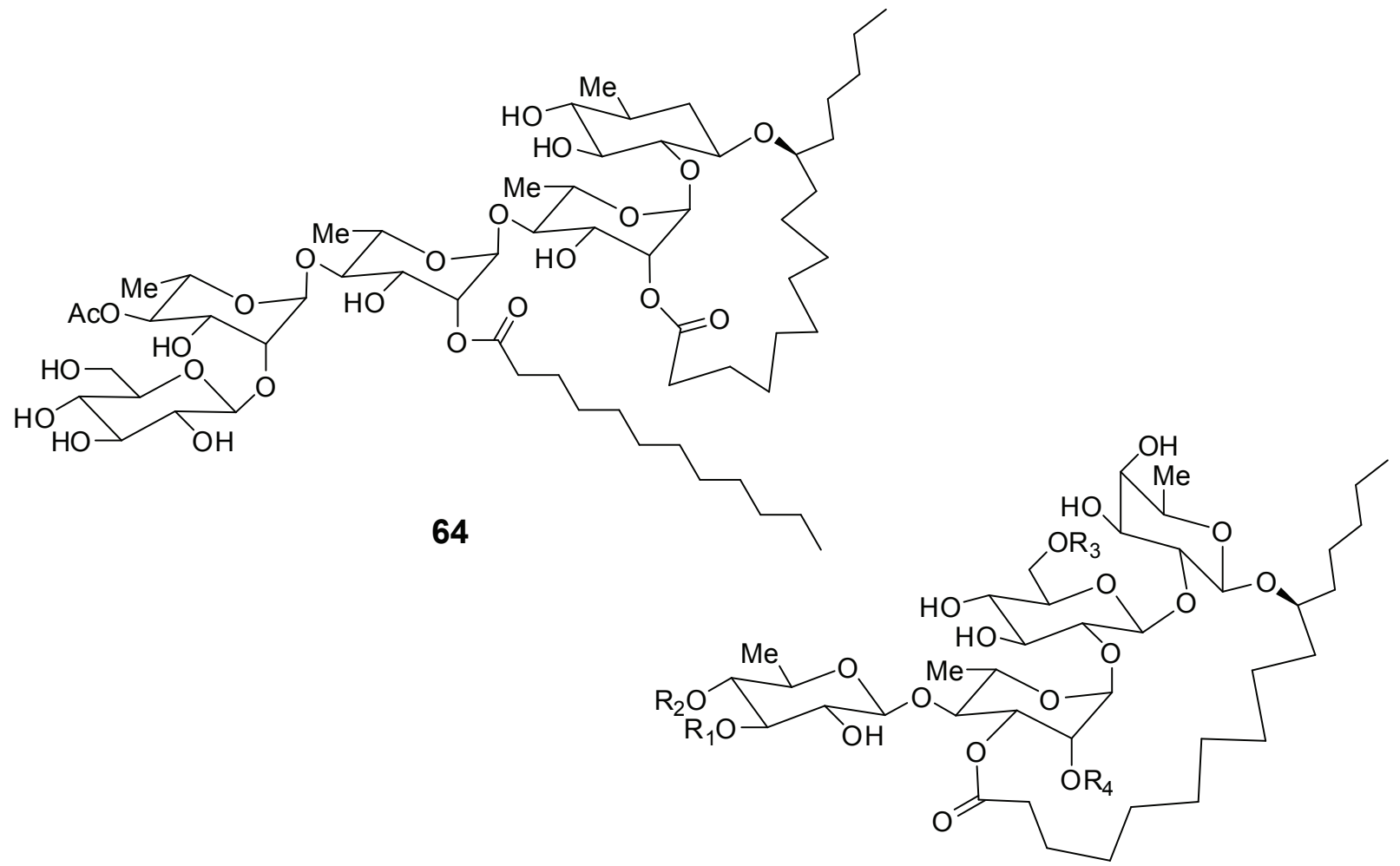

$65 \mathrm{R}_{1}=\mathrm{H}$; $\mathrm{R}_{2}=\alpha$-methyl-butanoyl; $\mathrm{R}_{3}=2$-methyl-3-hydroxy-butanoyl; $\mathrm{R}_{4}=$ tigloyl $66 \mathrm{R}_{1}=\mathrm{H} ; \mathrm{R}_{2}=$ isobutanoyl; $\mathrm{R}_{3}=2$-methyl-3-hydroxy-butanoyl; $\mathrm{R}_{4}=$ tigloyl

$67 \mathrm{R}_{1}=\mathrm{H} ; \mathrm{R}_{2}=\mathrm{R}_{3}=2$-methyl-3-hydroxy-butanoyl; $\mathrm{R}_{4}=$ tigloyl

$68 \mathrm{R}_{1}$ =isobutanoyl; $\mathrm{R}_{2}=\mathrm{H} ; \mathrm{R}_{3}=2$-methyl-3-hydroxy-butanoyl; $\mathrm{R}_{4}=$ tigloyl

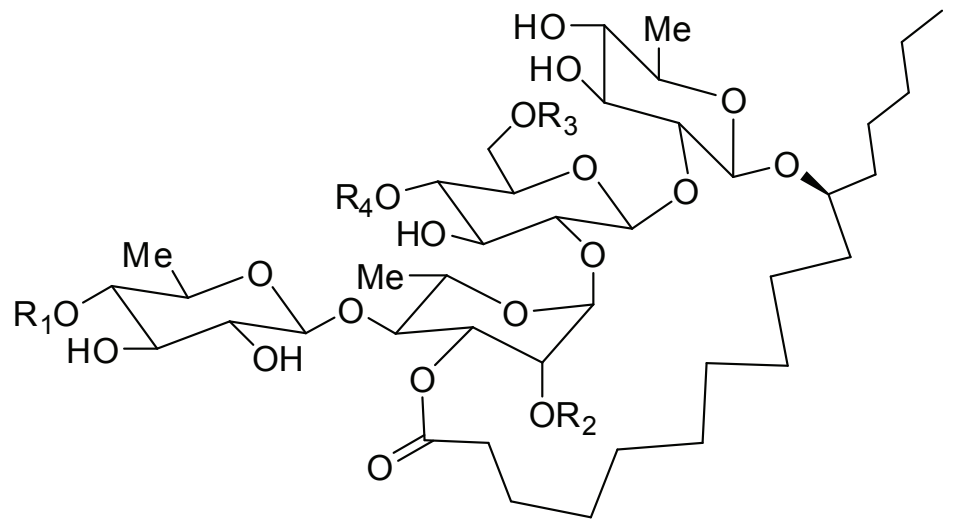

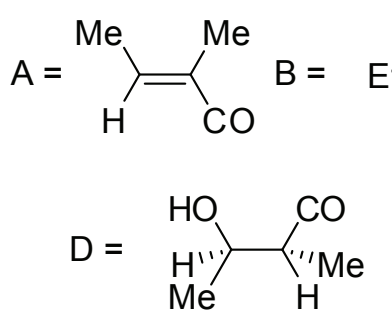<smiles>C=CC(C)C=O</smiles>

$E=$<smiles>CC(O)C(C)C=O</smiles>

$69 \mathrm{R}_{1}=\mathrm{D} ; \mathrm{R}_{2}=\mathrm{B} ; \mathrm{R}_{3}=\mathrm{R}_{4}=\mathrm{H}$

$70 \mathrm{R}_{1}=\mathrm{R}_{4}=\mathrm{H} ; \mathrm{R}_{2}=\mathrm{D} ; \mathrm{R}_{3}=\mathrm{B}$

$71 \mathrm{R}_{1}=\mathrm{R}_{4}=\mathrm{H} ; \mathrm{R}_{2}=\mathrm{B} ; \mathrm{R}_{3}=\mathrm{D}$

$72 \mathrm{R}_{1}=\mathrm{A} ; \mathrm{R}_{2}=\mathrm{B} ; \mathrm{R}_{3}=\mathrm{H} ; \mathrm{R}_{4}=\mathrm{D}$

$73 \mathrm{R}_{1}=\mathrm{A} ; \mathrm{R}_{2}=\mathrm{D} ; \mathrm{R}_{3}=\mathrm{C} ; \mathrm{R}_{4}=\mathrm{H}$

$74 \mathrm{R}_{1}=\mathrm{A} ; \mathrm{R}_{2}=\mathrm{E} ; \mathrm{R}_{3}=\mathrm{C} ; \mathrm{R}_{4}=\mathrm{H}$

$75 \mathrm{R}_{1}=\mathrm{A} ; \mathrm{R}_{2}=\mathrm{C} ; \mathrm{R}_{3}=\mathrm{D} ; \mathrm{R}_{4}=\mathrm{H}$

$76 \mathrm{R}_{1}=\mathrm{A} ; \mathrm{R}_{2}=\mathrm{C} ; \mathrm{R} 3=\mathrm{E} ; \mathrm{R} 4=\mathrm{H}$

77 R1=A; R2=D; $R_{3}=B ; R_{4}=H$

$78 \mathrm{R}_{1}=\mathrm{A} ; \mathrm{R}_{2}=\mathrm{E} ; \mathrm{R}_{3}=\mathrm{B} ; \mathrm{R}_{4}=\mathrm{H}$

$79 \mathrm{R}_{1}=\mathrm{A} ; \mathrm{R}_{2}=\mathrm{B} ; \mathrm{R}_{3}=\mathrm{D} ; \mathrm{R}_{4}=\mathrm{H}$

$80 \mathrm{R}_{1}=\mathrm{A} ; \mathrm{R}_{2}=\mathrm{B} ; \mathrm{R}_{3}=\mathrm{E} ; \mathrm{R}_{4}=\mathrm{H}$

$81 \mathrm{R}_{1}=\mathrm{B} ; \mathrm{R}_{2}=\mathrm{D} ; \mathrm{R}_{3}=\mathrm{B} ; \mathrm{R}_{4}=\mathrm{H}$

$82 \mathrm{R}_{1}=\mathrm{B} ; \mathrm{R}_{2}=\mathrm{E} ; \mathrm{R}_{3}=\mathrm{B} ; \mathrm{R}_{4}=\mathrm{H}$

$83 \mathrm{R}_{1}=\mathrm{B} ; \mathrm{R}_{2}=\mathrm{B} ; \mathrm{R}_{3}=\mathrm{D} ; \mathrm{R}_{4}=\mathrm{H}$

$84 \mathrm{R}_{1}=\mathrm{B} ; \mathrm{R}_{2}=\mathrm{B} ; \mathrm{R}_{3}=\mathrm{E} ; \mathrm{R}_{4}=\mathrm{H}$ 


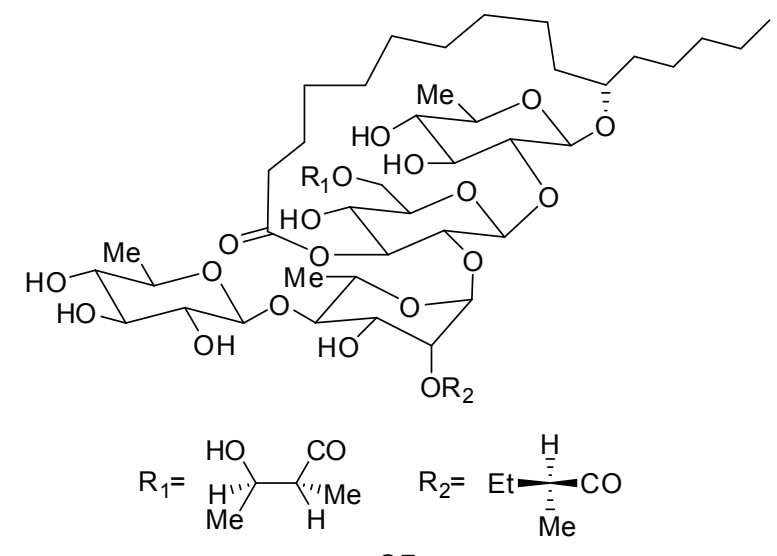

85

(2)

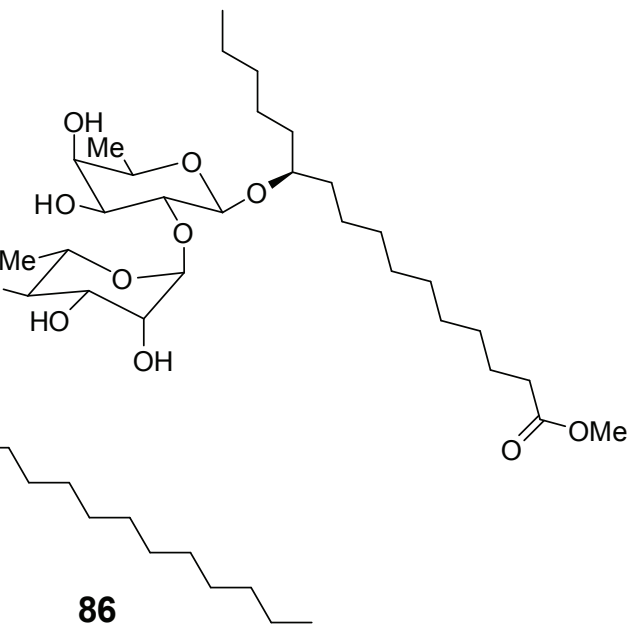

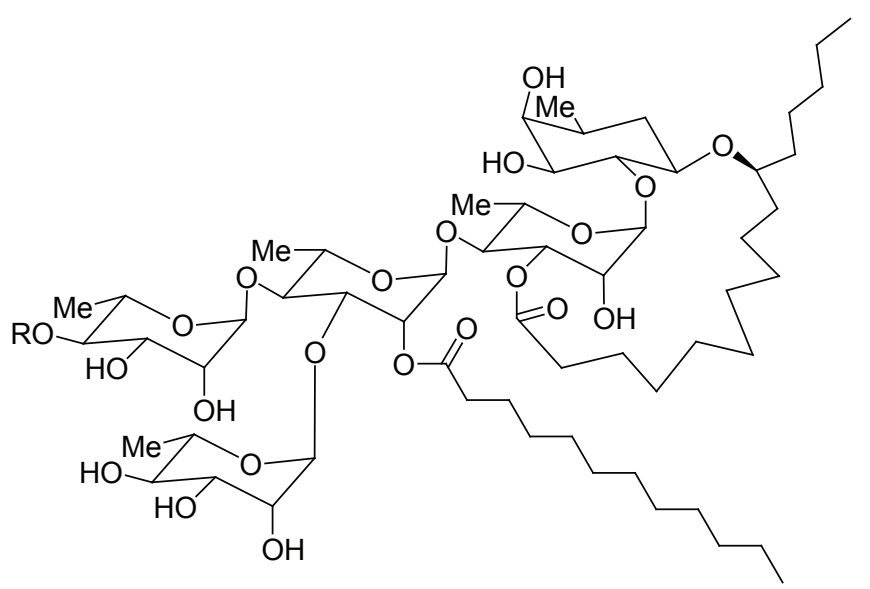

$87 \mathrm{R}=\mathrm{H}$

$88 \mathrm{R}=2$-methyl-propanoyl

$89 \mathrm{R}=(2 S)$-methyl-butanoyl

$90 \mathrm{R}=n$-hexanoyl

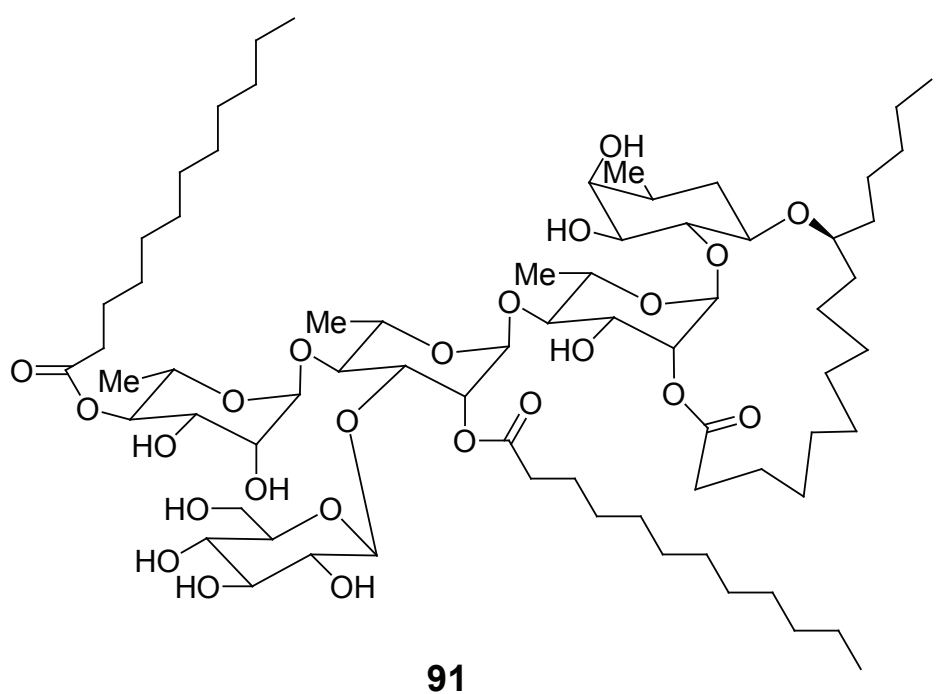




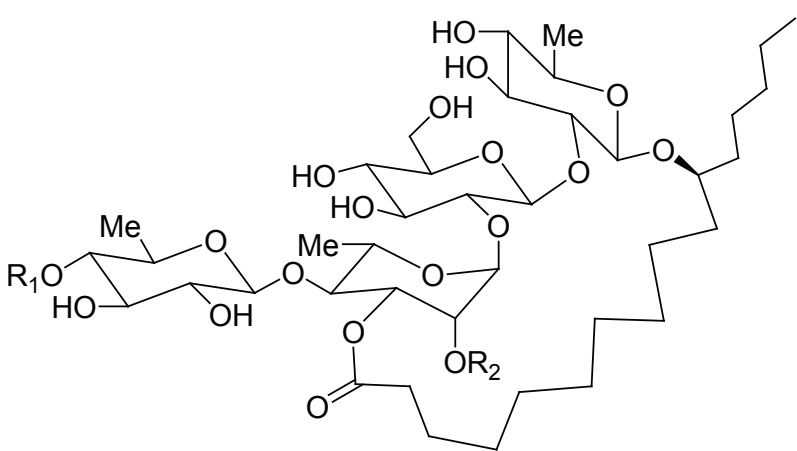

$92 \mathrm{R}_{1}=\mathrm{R}_{2}=2$-methyl-butanoyl

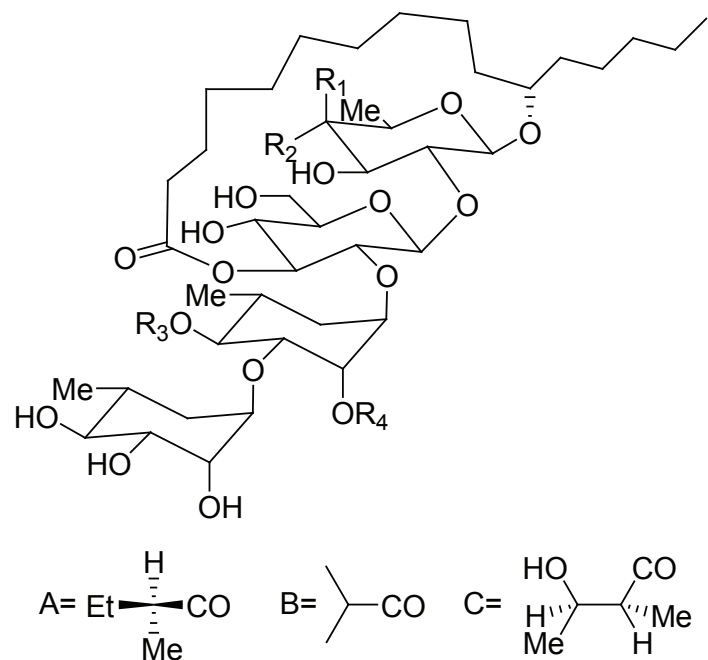

$93 \mathrm{R}_{1}=\mathrm{OH} ; \mathrm{R}_{2}=\mathrm{H} ; \mathrm{R}_{3}=\mathrm{R}_{4}=\mathrm{A}$

$94 \mathrm{R}_{1}=\mathrm{OH} ; \mathrm{R}_{2}=\mathrm{H} ; \mathrm{R}_{3}=\mathrm{B} ; \mathrm{R}_{4}=\mathrm{A}$

$95 \mathrm{R}_{1}=\mathrm{OH} ; \mathrm{R}_{2}=\mathrm{H} ; \mathrm{R}_{3}=\mathrm{C} ; \mathrm{R}_{4}=\mathrm{A}$

$96 \mathrm{R}_{1}=\mathrm{H} ; \mathrm{R}_{2}=\mathrm{OH} ; \mathrm{R}_{3}=\mathrm{R}_{4}=\mathrm{A}$

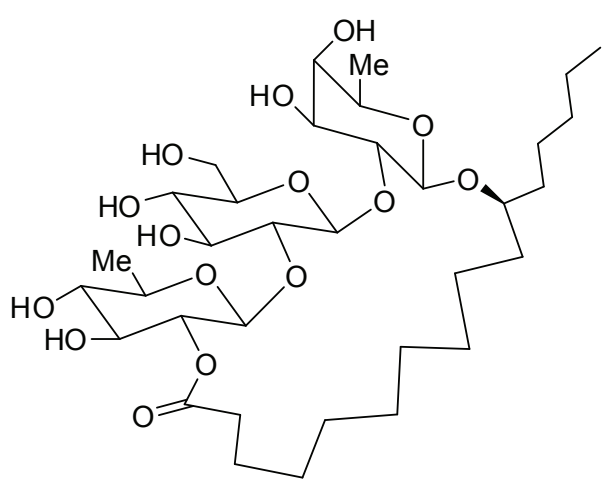

98

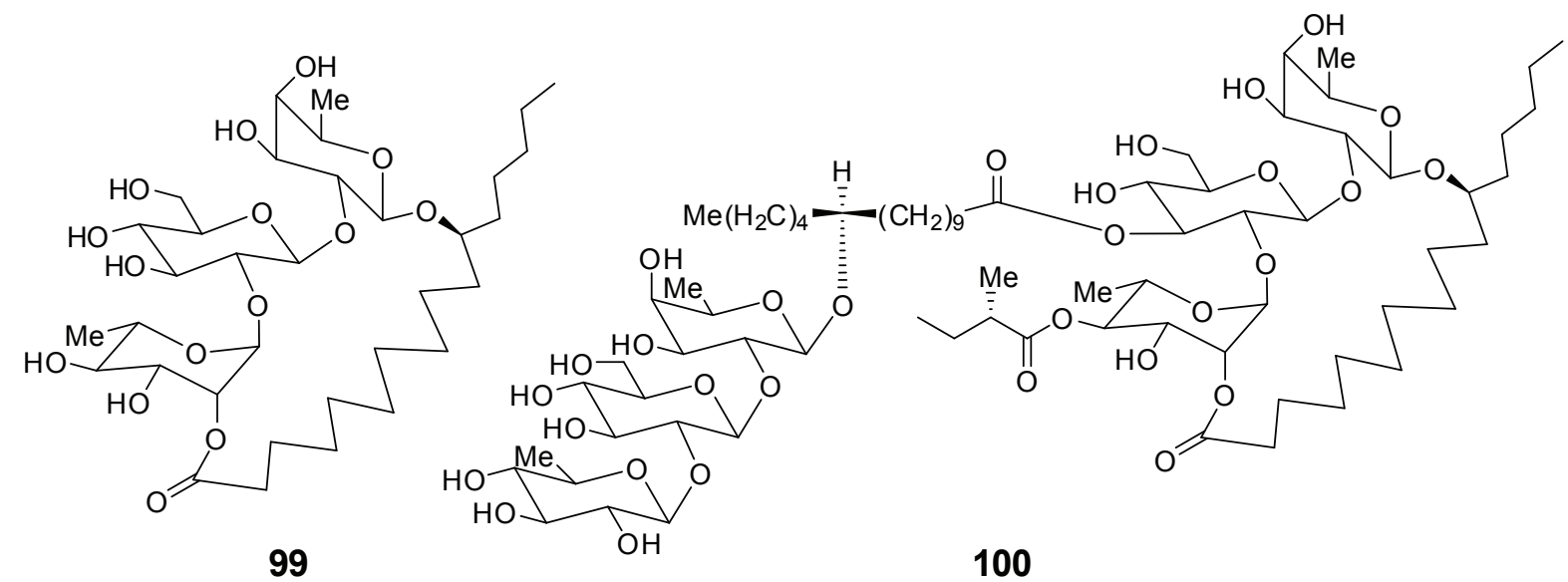



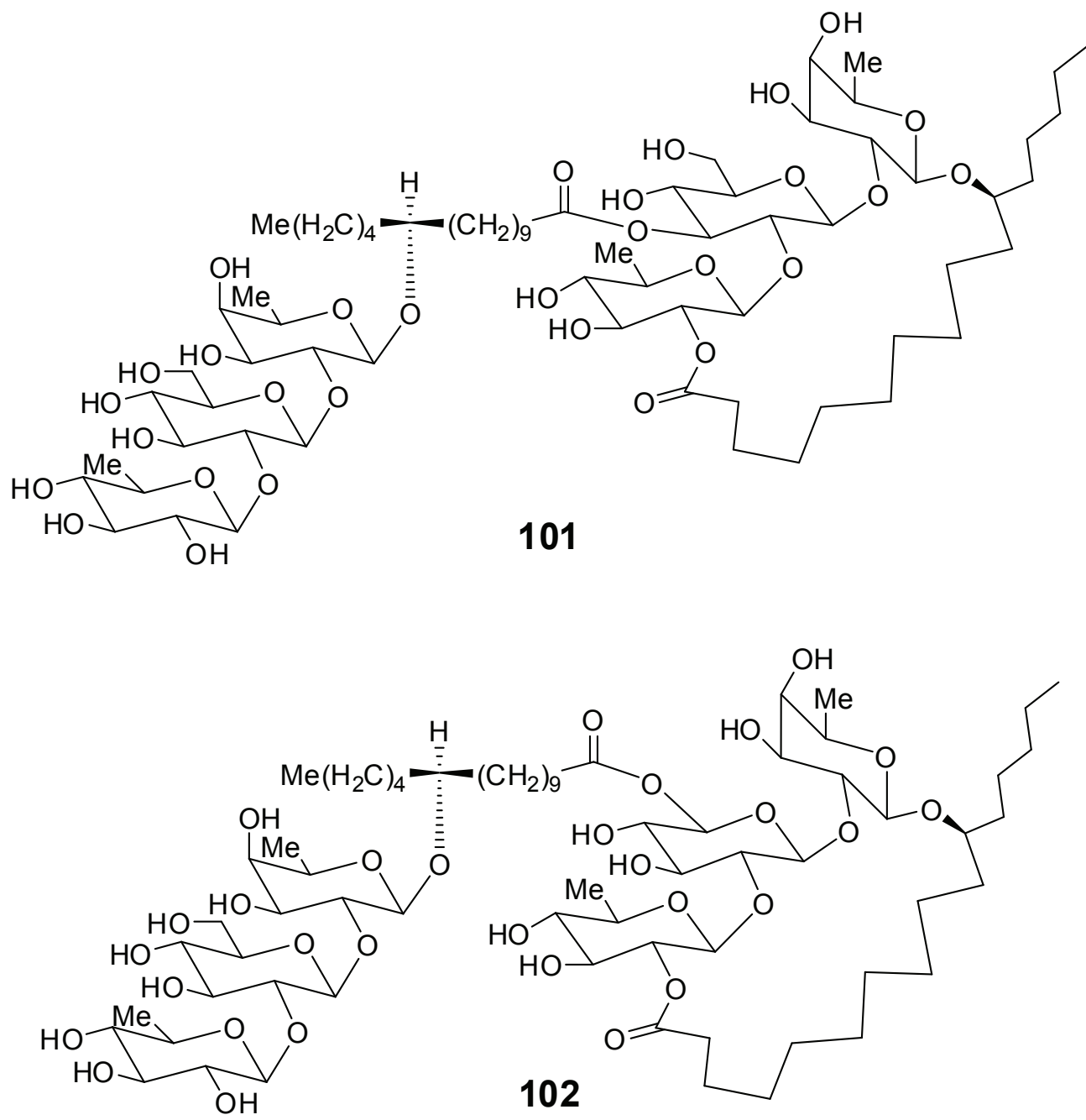<smiles>COc1cc(C[C@@H]2COC(=O)[C@H]2Cc2ccc(O)c(OC)c2)ccc1O</smiles> 
Review of the genus Ipomoea: traditional uses, chemistry and biological

\begin{tabular}{|lll|}
\hline Triterpene & & \\
\hline$\beta$-amirin acetate $\mathbf{( 1 0 4 )}$ & $\begin{array}{l}\text { I. batatas } \\
\text { I. pes-caprae }\end{array}$ & Antinociceptive \\
\hline$\alpha$-amirin acetate $\mathbf{( 1 0 5 )}$ & I. pes-caprae & Antinociceptive \\
\hline boehmeryl acetate $\mathbf{( 1 0 6 )}$ & I. batatas & $\begin{array}{l}\text { Ovopositional stimulant for Cylas } \\
\text { formicarius elegantulus }\end{array}$ \\
\hline $\begin{array}{l}\text { betulinic acid } \mathbf{( 1 0 7 )} \\
\text { glochidone } \mathbf{( 1 0 8 )}\end{array}$ & I. pes-caprae & Antinociceptive \\
\hline friedelin $(\mathbf{1 0 9})$ & I. batatas & $\begin{array}{l}\text { Antibacteriana against Staphylococcus } \\
\text { aureus and antifungal against } \\
\text { Pseudallescheria boydii }\end{array}$ \\
\hline taraxerol $\mathbf{( 1 1 0 )}$ & I. digitata & Acetylcholinesterase inhibitory \\
\hline
\end{tabular}

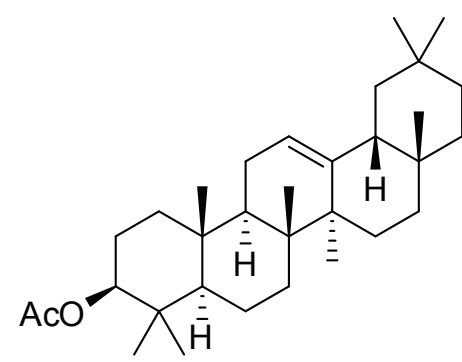

104<smiles>C=C(C)[C@H]1CC[C@]2(C(=O)O)CC[C@]3(C)C(CCC4[C@@]5(C)CC[C@@H](O)C(C)(C)C5CC[C@]43C)C12</smiles>

107

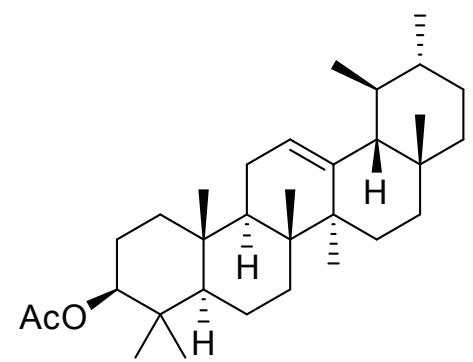

105<smiles>C=C(C)[C@@H]1CC[C@]2(C)CC[C@H](C)[C@]3(C)CCC4C(C)(C)C(=O)C=C[C@]4(C)[C@H]3CC[C@H]12</smiles>

108<smiles>CC(=O)O[C@H]1CC[C@]2(C)C3CCC4=C5CCC(C(C)C)[C@]5(C)CC[C@]4(C)C3CC[C@]2(C)C1(C)C</smiles>

106

109<smiles>CC1(C)CC[C@@]2(C)CC=C3[C@@]4(C)CC[C@]5(C)C(C)(C)[C@@H](O)CC[C@]5(C)[C@H]4CC[C@]3(C)[C@H]2C1</smiles> 


\section{I. alba $\mathrm{L}$.}

Indolizidine alkaloids were isolated from the seeds of $I$. alba: ipalbine ipalbidine, isoipomine, ipalbidinium, $E$-ipomine, $Z$-ipomine, methoxyipomine, dimethoxyipomine and ipohardine (Ikhiri et al., 1987; Gourley et al., 1969). Ipalbidine (13) demonstrated nonaddictive analgesic properties (Honda et al., 2003; Wang \& Chu, 1996). Moreover it showed inhibitory effects on respiratory burst of leukocytes and scavenged oxygen-free radicals (Chen \& Chu, 1998). Calystegines A5, B1 and B2 were isolated from the herbal material and roots of this plant (Schimming et al., 1998; 2005a). Calystegines B1 and B2 (16 and 17) are known to be potent inhibitors of rat lysosomal $\beta$-glucosidase (Haraguchi et al., 2003).

\section{I. aquatica Forssk.}

Calystegines B1 e B2 (16 and 17) beyond B4 were also found in I. aquatica (Schimming et al., 1998; 2005a). $N$-cis-Feruloyltyramine and $N$-transferuloyltyramine (20 and 21) isolated from roots of I. aquatica are inhibitors of prostaglandin synthesis (Tseng et al., 1986; 1992). An aqueous extract of $I$. aquatica showed as effective as the oral hypoglycaemic drug tolbutamide in reducing the blood sugar levels in rats (Malalavidhane et al., 2000; 2001). Isochlorogenic acids a, b and c (24-26) isolated of this species showed inhibitory activity of disaccharide-degrading enzyme. This research opens the possibility for the use of these substances as a food additive and a remedy for the prevention and treatment of diabetes and obesity (Okudaira et al., 2005). Isochlorogenic acids $a, b$ and $c$ (24-26) are also found in other species of Ipomoea, such as I. batatas and I. pes-caprae and exhibited colagenase inhibitory and were almost nocytotoxic (Teramachi et al., 2005), beyond to showed radical scavenging activities (Islam et al., 2003) and inhibition of HIV infection (Mahmood et al., 1993; Islam et al., 2002a). Isochlorogenic acids a (24) presents still antifungal activity (Stange et al., 2001) and significant anti-spasmodic activity (Trute et al., 1997).

Some studies showed the medicinal effects of this plant on liver diseases, eye diseases, and constipation (Malalavidhane et al., 2000). I. aquatica was screened for its activity against fibroblast cell lysis after Heterometrus laoticus scorpion venom treatment. However, the result was clearly negative (Uawonggul et al., 2006). Diuretic activity has been observed in extract of I. aquatica when investigated in the Swiss albino mice. This study supports the popular use of this plant as diuretic (Mamun et al., 2003).

The crude methanolic extract of I. aquatica, as well as, its column fraction and the purified compound
7-O- $\beta$-D-glucopiranosil-dihidroquercetina-3-O- $\beta$-Dglucopiranosideo (44) isolated from it, were investigated for cytotoxic properties against normal and cancer cell lines, Vero (normal African green monkey kidney) and Hep-2 (human larynx epithelial carcinoma) cell and A-549 (human small cell lung carcinoma). The purified compound showed cytotoxicity towards cell cultures with CTC50 values of $387 \mathrm{mg} / \mathrm{mL}$ against normal Vero cell line, where as 156 and $394 \mathrm{mg} /$ $\mathrm{mL}$, against Hep-2 and A-549 cell lines respectively.

The crude methanolic extract of I. aquatica and its column fraction gave CTC50 values ranging from 41$332 \mathrm{mg} / \mathrm{mL}$ in Vero, $46-114 \mathrm{mg} / \mathrm{mL}$ in Hep-2 and 44 - $230 \mathrm{mg} / \mathrm{mL}$ in A-549 cell lines. The crude extract was more potent than that purified compound probably due to the combination of anthocyanins and other phenolic compounds (Prasad et al., 2005a,b).

\section{I. asarifolia (Desr.) Roem. \& Schult.}

Four acylated anthocyanins were isolated of $I$. asarifolia (Pale et al., 1998; 2003). This species contain ergoline alkaloids such as chanoclavine I (2), ergine (4), ergobalansinine and lysergic acid $\alpha$-hydroxyethylamide (Jenett-Siems et al., 2004). Chanoclacine I (2) is a psychotomimetic agent and ergine (4) presents hallucinogenic and psychotomimetic effects. I. asarifolia is a toxic plant in Northeastern Brazil affecting goats, sheep and cattle. The clinical signs of tremorgenic sydrome caused by this plans include depression, tremors of the head, incoordinated gait, and hypermetria (Medeiros et al., 2003).

\section{Ipomoea batatas (L.) Lam.}

Recent study showed that white-skinned sweet potato (WSSP) called Caiapo presents active ingredients that can prevent and improve symptoms of diabetes and hypoglycemia as well as, stimulate the imune response, such as phagocytosis and phagosome-lysosome and have antiinflammatory effects (Miyazaki et al., 2005). Study in normal rats as well as in streptozotocin induced insulindeficient diabetic rats showed that WSSP have hipoglycemic activity and it increases blood insulin levels. WSSP suppressed the increase in blood glucose concentrations after glucose loading in normal rats and diabetic rats (Kusano et al., 1998; 2001; Kusano \& Abe, 2000). The antidiabetic component was located almost exclusively in the cortex of WSSP and is a high-molecular weight compound (22000) presumed to be an acidic glycoprotein because it contained protein and sugar (Kusano \& Abe, 2000). The study to investigate the tolerability, efficacy and mode of action of Caiapo extract on metabolic control in type 2 diabetic patients confirmed 
the beneficial effects of Caiapo on plasma glucose as well as cholesterol levels (Ludvik et al., 2002; 2003; 2004). The polysaccharide PSPP (purified sweet potato polysaccharide) isolated from the roots of $I$. batatas improve the immune system when tested in rats and could be regarded as a biological response modifier (Zhao et al.,

2005).

Other study confirmed than the extract from baked sweet potato showed potential cancer-preventing effects. Two fractions results of chromatography showed strong radical scavenging effects on DPPH radical coinciding with the high content of total phenolic compounds of them. These fractions suppressed strongly the proliferation of human promyelocytic leukemia cells (HL-60) with apoptosis inductions in a dependent manner. Besides, both of these fractions present antitumoral activity, when tested in mouse epidermal cell line (JB6) blocked the known tumor promotercalled TPA(12-O-tetradecanoylphorbol13-acetate) (Rabah et al., 2004). Extract of I. batatas caused marked dose-dependent growth inhibition in several human colon carcinoma cell lines with IC50 values in the range of $20-50 \mu \mathrm{g} / \mathrm{mL}$ for HCT 116 , SW480, HT29 and SW837 cell lines. However, the IC50 value was more than $100 \mu \mathrm{g} / \mathrm{mL}$ when $\mathrm{CaCo} 2$ cells were tested (Kaneshiro, et al., 2005). An indole-type alkaloid called Ipomine A was isolated of the hairy roots of I. batatas (Yuan et al., 2004). Calystegines B1 and B2 (16 and 17) that are potent inhibitors of rat lysosomal $\beta$-glucosidase (Haraguchi et al., 2003) besides A3, B3 and the alkaloid $2 \alpha, 7 \beta-$ dihidroxinortropano were identified in the roots of $I$. batatas (Schimming et al., 1998, 2005a). Study in rats has shown that $I$. batatas leave are a good source of polyphenols, antioxidants and displayed vascular relaxing properties. These effects have been reported to reduce the risk of cardiovascular disease (Runnie et al., 2004). From I. batatas leaves were isolated the isochlorogenic acids a, b and c (24-26), also found in $I$. aquatica and $I$. pes-caprae, whose biological activities already were described. Chlorogenic acid (23) and 3,4,5tri-O-caffeoylquinic acid (27) were also found in $I$. batatas. These compounds are also inhibitors of HIV replication (Mahmood et al., 1993) and present hypoglycaemic (Okudaira et al., 2005), radical scavenging (Islam et al., 2003) and antimutagenic (Yoshimoto et al., 2002) activities. Chlorogenic acids were not detected in the root. The stem also contained three feruloylquinic acids and small amounts of at least four caffeoyl-feruloylquinic acids (Zheng \& Clifford,

2008).

The roots of $I$. batatas contain the coumarins aesculetin (35) (Minamikawa et al., 1962), scopoletin (34) and umbelliferone (36) which have anti-coagulation properties and inhibit HIV replication (Cambie \& Ferguson, 2003). Scopoletin (34) presents also hepatoprotective (Kang et al., 1998), antioxidant (Shaw et al., 2003), spasmolytic (Oliveira et al., 2001) and acetylcholinesterase (AchE) inhibitory (Lee et al., 2004) activities, as well as, inhibited proliferation by inducing apoptosis of human adrogen-independent protate adenocarcinoma cells (PC3) (Liu et al., 2001). Scopoletin (34) is a member of the phytoalexins of I. batatas (Lima \& Braz-Filho,

1997).

Vitamin C, caffeic acid and flavonoids, such as, rutin, quercetin (Guan et al., 2006), tiliroside, astragalin, rhamnocitrin, rhamnetin and kaempferol (Luo \& Kong, 2005), cyanidins and peonidins (45-54) (Islam et al., 2002b; 2003; Terahara et al. 1999; Yang \& Tsai, 1999; Lee et al., 1997; Goda et al., 1997; Odake et al., 1992; Tsukui et al., 1983) are also found in this species. The anthocyanins were stronger activity than ascorbic acid in the test in vitro DPPH radical-scavenging activity. Besides, these anthocyanins showed also antioxidative activity in vivo (Kano et al., 2005). Anthocyanidins occur, in general, in the periderm cell walls of the storage roots (Philpott et al., 2009).

The water extract from the roots of purple sweet potato Ayamurasaki variety inhibited strongly the mutagenicity of Salmonella typhimurium. However, an anthocyanin-deficient mutant of Ayamusasaki inhibited weakly the mutagenicity, suggesting that the anthocyanins pigments, which are abundant in the normal Ayamurasaki, decrease the mutagenic activity of the mutagens (Yoshimoto et al., 1999). The antimutagenicity of the anthocyanins isolated of sweet potatos with purple-colored flesh was also investigated using Salmonella typhimurium. A comparation of the results showed that the cyanidin-type anthocyanin was superior to the peonidin-type in ts antimutagenicity (Yoshimoto et al., 2001). Other study showed that the diacylated anthocyanins such as the peonidin 3-O-(2-O-(6-O-Eferuloyl- $\beta$-D-glucopyranosyl)-6- $O$ - $E$-caffeoyl- $\beta$-Dglucopyranoside)-5-O- $\beta$-D-glucopyranoside (54) isolated of the roots and leaves of $I$. batatas present postprandial anti-hyperglycemic effect when tested in rats through the retardation of maltase activity (Matsui et al., 2002).

Bioactive triterpenes were also found in $I$. batatas, such as, boehmeryl acetate (106) that age as an ovipositional stimulant for the sweet potato weevil, Cylas formicarius elegantulus Summers (Son et al., 1990), friedelin (109), that demonstrated good activity against S. Aureus compared with ampicillin and amoxicillin, and good antifungal activity against Pseudallescheria boydii (Kilham, 2004; Tan et al., 1995) and $\beta$-amyrin acetate (104) that showed pronounced antinociceptive properties in the writhing test and formalin test in mice (Tan et al., 1995; Krogh et al., 1999).

The $\mathrm{CHCl}_{3}$ extract from the roots of I. batatas presented significant phytotoxicity and the active constituents isolated were a serie of resin glycosides 
called simonins I-V (Baek et al., 1997; Noda et al., 1992). The major constituent simonin IV (91) presented phytotoxicity when tested pure (Pereda-Miranda \& Bah, 2003). The extract of sweet potato exhibits still hepatoprotective (Suda et al., 1997), antiinflamatory, antimicrobial, antihypertensive activities and has ultraviolet protection effects (Yoshimoto, 2001). The roots of $I$. batatas when molded (infected with Fusarium solani) are toxics. Animals consuming molded sweet potatoes produce a characteristic and often lethal respiratory disease. Tests in vitro with the major constituents, called 4-ipomeanol (1-(3-fury1)-4hydroxypentanone) (Boyd \& Wilson, 1972) showed that this compound presents citotoxic activity (Krauss \& Unterreitmeier, 2005). From the tubers of Ipomoea batatas were isolated nine new lipo-oligosaccharides, batatosides $\mathrm{H}-\mathrm{P}$. Of these, only batatosides $\mathrm{L}$ and $\mathrm{O}$ showed a weak inhibitory effect on the growth of Hep-2 cells, while the others proved to be inactive (Yin et al., 2009). From the tuber of Ipomoea batatas were also isolated two saponines. Their antioxidants activities tested by DPPH and FRAP assay were moderate in relation to commercial standards (Dini et al., 2009). Tuberous roots of Ipomoea batatas contain a large amount of storage protein being sporamin the major. The principal function of the storage proteins is nutritional resource for seed germination or tuber regrowth. Recent study showed that exist a linear relationship between trypsin inhibitor activity (Ti activity) and amounts of sporamin B (Sun et al., 2009).

\section{Ipomoea bahiensis Willd. ex Roem. \& Schult.}

Four antimicrobial glycosides have been isolated from Ipomoea bahiensis. One of these compounds revealed significant activity against Sarcoma 180 in mice (Bieber et al., 1986). Forssk.)

Ipomoea cairica (L.) Sweet (Syn. I. palmata

Aqueous extract from I. cairica showed antiRSV (respiratory syncytial virus) activity in vitro (Ma et al., 2002). The ethanolic extract of this plant presents an antinociceptive effect (Ferreira et al., 2006). The major constituents of the extract were the coumarins scopoletin (34) and umbelliferone (36) and the lignans, arctigenin, matairesinol and trachelogenin (Lima \& Braz-Filho, 1997). Arctigenin (103) was the most cytotoxic and presents also antioxidant and antiinflammatory activities (Cho et al., 2004), as well as, inhibited the replication of human immunodeficiency virus (Eich et al., 1996). The essential oil of $I$. cairica possesses remarkable larvicidal properties. It could induce $100 \%$ mortality in the larvae of Culex tritaeniorhynchus (100 ppm), Aedes aegypti (120 ppm), Anopheles stephensi (120 ppm) and Culex quinquefasciatus (170 ppm) (Thomas et al., 2004). Indole alkaloids were isolated from the leaves of this specie (Sharda \& Kokate 1979).

Ipomoea carnea Jacq. subsp. fistulosa (Mart. ex. Choisy) D.F. Austin (syn. I. fistulosa Mart. ex Choisy).

Pharmacological studies, conducted on rats, with the non-alkaloidal and non-saponifiable fraction isolated from the leaves of I. carnea showed the depressant activity of this species on the Central Nervous System (Ehattacharya \& Ray, 1975). In study for screening the HIV-1 RT inhibitory potential of medicinal plant, at a concentration of 200 $\mu \mathrm{g} / \mathrm{mL}$, crude water extracts of I. carnea subsp. fistulosa (aerial parts), proved to be strongly active with 98,95\% of inhibition (Woradulayapinij et al., 2005). Other study for evaluation of immunomodulatory activity of this species on peritoneal cells of rats suggest that low dosages of $I$. carnea induced enhanced phagocytosis activity and hydrogen peroxide production by macrophages (Hueza et al., 2003a). The extract of I. carnea subsp. fistulosa presents antiinflammatory activity when tested in rats (Gorzalczany et al., 1996). The extract from the leaves of this species was tested in vitro against the adenocarcinoma de colon (L-HT29C) and human lymphocyte (L-THP) and presented no cytotoxicity (Lamidi et al., 2000).

Polyhydroxylated alkaloids were isolated from flowers, leaves and seeds of I. carnea subsp. fistulosa and characterized as 2-epi-lentiginosine (14), swainsonine (15), calystegines B1 (16), B2 (17), C1 (18) and B3 (19) and $N$-methyl-trans-4-hydroxy-Lproline (Haraguchi et al., 2003). When tested in rats, the calystegines B1 (16), B2 (17) and C1 (18) were potent inhibitors of lysosomal $\beta$-glucosidase and calystegine B3 (19) showed a moderate inhibitory activity toward $\alpha$ and $\beta$-lysosomal mannosidases. The compounds 2-epi-lentiginosine (14) and swainsonine (15) showed a potent inhibitory activity toward rat lysosomal $\alpha$-mannosidase. The inibitions of this enzimes result in lysosomal accumulation of undegraded oligosaccharides, vacuolation and cell death (Haraguchi et al., 2003; Ikeda et al., 2003). From leaves of this specie were isolated agroclavin (1) and dihydrolysergol (Umar et al., 1980).

I. carnea e I. carnea subsp. fistulosa cause serious intoxication of livestock. The animals, such as cattle, sheep, and goats (Górniak et al., 2010) presents intoxication clinically characterized by inappetence, soft feces, and weight loss, disorders of behaviors and consciousness, incoordinated gait, head shaking and death (Haraguchi et al., 2003; Daló \& Moussatché, 1978; De Balogh et al., 1999). The toxic principles of this plant 
have been identified as the alkaloids swainsonine (15) and calystegines B1 (16), B2 (17), C1 (18) and B3 (19) (Hueza et al., 2005, Haraguchi et al., 2003). The studies suggest that calystegines may act as coadjuvants of swainsonine in I. carnea toxicosis (Ikeda et al., 2003; Hueza et al., 2005). Other study showed that when administrated to pregnant rat toxic principle of I. carnea to pass through the placenta promoted decreased body weight, thymus atrophy and spleen enlargement in pups (Hueza et al., 2003b). Ipomoea carnea also promotes changes in lymphocyte distribution of young rats (Pípole et al., 2010). From latex of I. carnea was found a new chitinase, a digestive enzyme that break down glycosidic bonds in chitin (Patel et al., 2009; 2010). Caffeoyl derivatives were isolated from the seeds of Ipomoea fistulosa (Sattar et al., 1995). The aqueous extract of I. carnea Brazillian presented $0.09 \%$ swainsonine, $0.11 \%$ calystegine $\mathrm{B} 2,0.14 \%$ of calystegine B1, $0.06 \%$ calystegine $\mathrm{C} 1$ and the no proteic imino acid $N$-methyltrans-4-hydroxy-L-proline (Schwarz et al., 2004).

$$
\text { Ipomoea corymbosa (L.) Roth ex Roem. \& }
$$

Schult.

I. corymbosa (Rivea corymbosa) is known by psychomimetic active principles of its seeds, the ancient Aztec drug "ololiuqui". In the seeds of this species were found alkaloids of the ergot type, such as, d-lysergic acid amide or LSA, also called ergine (4), as the major component in ololiuqui seeds as well as, the following minor alkaloids: chanoclavine I (2), elymoclavine (3), D-isolysergic acid amide also called erginine or isoergine (5) and lysergol (11) (Hoffmann, 1971). LSA or ergine (4) is a close analogue of best-know syntetic LSD (lysergic acid diethylamide). Hallucinogenic activity of LSA occurs with 2-5 mg, while LSD occurs at the microgram level (Halpern, 2004; Hoffmann, 1971). Elymoclavine (3), erginine (5) and lysergol (11) are also known to be psychoactive in humans (Hoffmann, 1963; Hoffmann \& Tscherter, 1960; Hoffmann \& Cerletti, 1961; Der Marderosian \& Youngken Jr, 1966; Steinegger \& Heimann, 1966; Ferrari, 1979).

\section{Ipomoea digitata $\mathrm{L}$.}

The ether-sol. fraction of I. digitata presented hypotensive and muscle relaxant activity when tested in frogs, dogs, rats and rabbit (Tewati \& Mishra, 1965). A glycoside called paniculatin isolated from the tubers of I. digitata, showed a stimulant effect on myocardium and respiration, a vasoconstrictor and bronchoconstrictor effect, a spasmogenic effect on smooth muscles of gut, as well as, it elevated the blood pressure, and also presented oxytocic activity (Matin et al., 1969a; $1969 \mathrm{~b})$. Other constituents isolated from the roots of this plant are taraxerol, taraxerol acetate, $N$-butyl- $\beta$-Dfructopyranoside, octadecyl $(E)$-p-coumarate and the coumarins umbelliferone, scopoletin, scopolin (Dai et al., 2000) and scoparone (Rao et al., 1984). Scopoletin (34) and taraxerol (110) inhibited AChE (acetylcholinesterase) activity. This enzyme is responsible for the metabolic hydrolysis of the neurotransmitter acetylcholine. AchE inhibitors are important for the treatment of Alzheimer's disease. Memory impairments in this patients result from a deficit of cholinergic functions in the brain (Lee et al., 2004).

\section{Ipomoea hederacea Jacq.}

Methanolic extract of $I$. hederacea showed a strong cytotoxic potential when tested in in cultured human lung (A549) and colon (Col 2) cancer cells (Nam \& Lee, 2000). I. hederacea seeds contained chanoclavine I (2), elymoclavine (3), lysergol (11) and penniclavine (12) known to be psychoactive and isopenniclavine (AbouChaar, 1967).

\section{Ipomoea hederifolia L.}

From I. hederifolia were identified the active calystegines B1 (16) and B2 (17) (Haraguchi et al., 2003) besides A5 (Schimming et al., 1998). Moreover, several pyrrolizidine alkaloids of the ipanguline-type were isolated from I. hederifolia (Jenett-Siems et al., 1993; 1998).

\section{I. horrida Huber}

From the aerial parts of $I$. horrida were identified 7,4'-di- $O$-methylkaempferol and 7,3',4'-tri- $O$ methylquercetin (Barbosa-Filho et al., 1996).

\section{Ipomoea imperati (Vahl) Griseb.}

Methanol-water extract from the leaves of $I$. imperati showed local and systemic anti-inflammatory actions in mice and rats, respectively. This extract also presented antispasmodic activity on the isolated ileum, inhibiting histamine and acetylcholine. In the acute toxicity assay, $1 \mathrm{mg} / \mathrm{kg}$ of $I$. imperati methanol-water extract caused no mortality in mice after $24 \mathrm{~h}$ (Paula et al., 2003). Ipomoea imperati prevented the formation of gastric lesions in $78 \%(p<0.05)$ when compared with the negative control tween 80 (Miyahara et al., 2011). Ethanol extract, lipid and aqueous fraction of I. imperati significantly inhibited the abdominal constriction in mice induced by acetic acid; increased the sleeping time evoked by pentobarbital sodium and showed a significant activity by inhibiting formalin-induced paw edema in mice (Paula- 
Zurron et al., 2010).

Br.)

Ipomoea indica (Burm.) Merr. (I. congesta R.

Methanolic extract from the seeds of $I$. indica (I. congesta) presented biological activity against Herpes Simplex-1 (Locher et al., 1995). Methanolic and aqueous extracts from the seeds of this species were also investigated for anti-bacterial activity against Streptococus pyogenes, Staphylococus aureus, Pseudomonas aeruginosa and Escherichia coli. However, they did not present activity (Locher et al., 1995). Acetonitrile extract from the seeds of I. indica (I. congesta) was evaluated for its ability to inhibit the growth of three species of fungi, Microsporum canis, Epidermophyton floccosum and Trichophyton rubrum. I. indica (I. congesta) showed activity against Microsporum canis and Epidermophyton floccosum at a concentration of $1000 \mu \mathrm{g} / \mathrm{mL}$ but no growth inhibition was observed against Trichophyton rubrum (Locher et al., 1995). The glycoside called ipolearoside, with significant activity against Walker carcinosarcoma 256 in rats, has been isolated from ethanol extracts of the whole plants of I. leari Paxt. (I. indica) (Sarin et al., 1973).

\section{Ipomoea involucrata P. Beauv.}

Petroleum ether and ethanol extracts of $I$. involucrata were were subjected to biological screening using Klebsiella spp., Escherichia coli, Pseudomonas aeruginosa and Staphylococcus aureus. The extracts inhibited the growth of both Gram-positive and Gramnegative organisms (Ejimadu \& Ogbeide, 2001). Aqueous ethanolic extract of $I$. involucrata showed a true antiviral activity against herpes simplex virus type 1 (HSV 1) and a virucidal activity against VSV T2 (Vesicular stomatitis virus T2) SF A7 (Semliki forest virus A7) and MV-EA (Measles virus strain Edmonston A) (Sindambiwe et al., 1999).

\section{Ipomoea leptophylla Torr.}

The crude organic extract $\left(\mathrm{MeOH}-\mathrm{CH}_{2} \mathrm{Cl}_{2}\right)$ of I. leptophylla presented $92 \%$ inhibition at $150 \mu \mathrm{g} /$ $\mathrm{mL}$ against $M$. tuberculosis in vitro. Bioassay-guided fractionation of this extract resulted in the isolation of two resin glycosides called leptophyllins A and B. However, these compounds presented weak or no activity when tested in the anti-tuberculosis assay. Upon the basis of the activity of the extract it appears that there may be other minor metabolites that contribute to the extract's anti-tuberculosis activity (Barnes et al., 2003).

Ipomoea lonchophylla J.M. Black
In Austrália occurs the "dumb lamb syndrome" that causes mortallity among newly born lambs. It is believe that this disease occurs during gestation when the female feed toxic species. I. lonchophylla J. Black has been implicated in this disorder. One fraction from $I$. lonchophylla was toxic to mice but no tests have so far been carried out to determine whether this toxic fraction contribute to intoxication and death among newly born lambs. The toxic fraction contained an inseparable mixture of resin glycosides (Macleod et al., 1997).

\section{Ipomoea muelleri Benth.}

Several ergoline alkaloids, known to be psychoactive in humans, were isolated from the seeds of I. muelleri, such as agroclavine (1), chanoclavine I (2), elymoclavine (3), ergine or LSA(4), erginine or isolysergic acid amide (5), ergometrine (8), festuclavine (10), lysergol (11), penniclavine (12), as well, isopenniclavine, $\alpha$-dihydrolysergol, Isolysergol, isosetoclavine, setoclavine, molliclavine, isolysergamide, $N$-(1hydroxyethyl) chanoclavine II and ergometrinine (Der Marderosian et al., 1974; Hoffmann, 1963). Agroclavine (1) and festuclavine (10) were shown to be effective antimicrobial compounds and had significant cytostatic activity to a mouse lymphoma cell line. Agroclavine (1) was also effective at inhibiting $E$. coli multiplication (Panaccione, 2005). Ergometrine or ergonovine (8) has potent uterine againstction activity and is used as an oxytocic and in treating postpartum hemorrhages. Bleeding is reduced because of its vasoconstrictor effects (Dewick, 2002).

\section{Ipomoea muricata (L.) Jacq.}

The seeds of $I$. muricata presented analgesic and antiseptic properties (Ysrael, 2003). The indolizidine alkaloidal ipalbine, ipalbidine, ipalbinium and ipomine were isolated from the seeds (Exconde et al., 2004). Analgesic properties have been attributed for ipalbidine (13) (Honda et al., 2003; Dawidar et al., 1977). Antimicrobial and antifungal compounds were also identified (Ysrael, 2003). The indolizidine alkaloid caled $E$-ipomine were also isolated in the seeds of $I$. muricata (Dawidar et al., 1977) besides cafeic acid, (Misra \& Tewari, 1952), muricatins A and B (Misra \& Tewari, 1953), muricatins I-VIII (Noda et al., 1985; 1988a; 1988b) and muricatics acids A, B and C (Noda et al., 1988c). Of these, cafeic acid (22) presents antioxidant and antimutagenic activities (Yoshimoto et al., 1999) and muricatin $\mathrm{A}$ in doses of $20-40 \mathrm{mg} / \mathrm{kg}$ to anesthetized dogs produced a fall in blood pressure with subsequent 
rise to the original level. Muricatin B presented no pharmacological activity (Chaudhary et al., 1957).

\section{Ipomoea murucoides Roem. \& Schult.}

From the roots of I. murucoides (cazahuate) were isolated the glycoresins called murucins 1-5. Murucin 1 (64) presents marginal activity (ED50 $5.0 \mu \mathrm{g} / \mathrm{mL}$ ) against ovarian carcinoma (OVCAR-5) cells, but was inactive (ED50 $>20.0 \mu \mathrm{g} / \mathrm{mL}$ ) against colon carcinoma (HCT-15) and cervical carcinoma (UISO-SQC-1) cells. Murucins 2-5 were inactive against all three of these cell lines (León et al., 2005). From flowers of Ipomoea murucoides were isolated five lipophilic tetrasaccharide called murucoidins XII-XVI. These compounds were tested for in vitro antibacterial and resistance modifying activity against strains of Staphylococcus aureus possessing multidrug resistance efflux mechanisms. Only murucoidin XIV showed antimicrobial activity against SA-1199B a norfloxacin-resistant strain that over-expresses the NorA MDR efflux pump (Chérigo et al., 2009).

\section{Ipomoea nil (L.) Roth}

Ethanol extract from the roots of I. nil (Pharbitis nil) induce growth inhibition and apoptosis of human gastric cancer cells (AGS) (Ko et al., 2004). From this species were also isolated peonidins (Saito et al., 2005) and the anthocyans HBA (56) that presents protective effects against UV-B (Mori et al., 2005). A spermidine alkaloid, N1, N10-ditigloylspermidine were isolated from the seeds of I. nil (Schimming et al., 2005b).

\section{Ipomoea obscura (L.) Ker Gawl.}

Methanolic seed extract of I. obscura afforded indole alkaloids, such as ipobscurines B-D (Jenett-Siems et al., 2003). Active calystegins B1 (16), B2 (17), C1(18) and B3 (19), besides calistegin B4, and were also isolated of this species (Asano et al., 2001; Schimming et al., 1998). Steud.

Ipomoea orizabensis (G. Pelletan) Ledeb. ex

I. orizabensis produced strong activity against sarcoma 37 (Belkin et al., 1952). From the roots of this species were isolated several glycoresins: scammonine I (57) a complex glycolipid active against methacillinresistant staphylococci (Mitscher \& Telikepalli, 1992), scamonin II (58) and orizabins V a VII (69-71) which are weakly cytotoxic (ED50 4-20 $\mu \mathrm{g} / \mathrm{mL}$ ) against human oral epidermoid carcinoma (KB) (Hernandez-Carlos et al., 1999), orizabins I-IV (65-68) useful as laxatives (Noda et al., 1985; 1987), orizabin VIII (85) that presents weak cytotoxicity against colon carcinoma and orizabins IXXXI (72-84) which exhibited citotoxic activity (ED50 1-5 $\mu \mathrm{g} / \mathrm{mL}$ ) against oral epidermoid carcinoma (KB) but exhibited a weak cytotoxicity against colon carcinoma (HCT-15), squamoux cell cervix carcinoma (SQC-1) and ovarium cancer (OVCAR) cell lines (ED50 4-20 $\mu \mathrm{g} /$ mL) (Pereda-Miranda \& Hernández-Carlos, 2002). These glycolipids contain an intramolecular macrocyclic lactone (Noda et al., 1990).

Ipomoea operculata Mart. et Spix. (syn. Operculina macrocarpa (L.) Urb.)

Several glycoresins called operculins I-XVIII were isolated from the roots of I. operculata. However its biological activities were not evaluated (Ono et al., 1989; 1990; 1991; 1992a).

\section{Ipomoea parasitica (Kunth) G. Don}

The petroleum ether extract from the seeds of $I$. parasitica (HBK) Don. were isolated a unique members of a class of glycoresin (Smith et al., 1964). From seeds of this species were identified lysergol and elymoclavine besides other ergoline alkaloids (Amor-Prats \& Harborne, 1993a).

\section{Ipomoea pes-caprae (L.) R. Br.}

This specie is known as salsa-da-praia or batateira-da-praia in Brazil (Souza et al., 2000) and Railroad vine, bay hops or beach morningglory in North America (Pereda-Miranda et al., 2005). To identify potential migraine therapeutics, I. pes-caprae was screened to detect inhibitors of platelet $\left({ }^{14} \mathrm{C}\right)$ 5-hydroxytryptamine $(5-\mathrm{HT})$ release. Studies showed that the methanolic extracts of I. pes-caprae was potent inhibitors of platelet (14C)5-HT release, even after the addition of PVP (polyvinyl pyrrolidone) to remove polyphenolic tannins that precipitate proteins (Rogers et al., 2000).

Study in mice indicated that both methanolic extract and two fractions (ethyl acetate and aqueous) exhibited antinociceptive activity against two classical models of pain, neurogenic and inflammatory. This study justifies at least in part, the traditional use of this plant to treat dolorous process (Souza et al., 2000). Some constituents isolated from I. pes-caprae, such as, quercetin 3-O- $\beta$-D-glucofuranoside (55), $\beta$-amyrin acetate (104) $\alpha$-amyrin acetate (105), betulinic acid (107) and glochidone (108) showed pronounced antinociceptive properties in mice. These data confirm the previous work concerning the antinociceptive action of the 
hydroalcoholic extract of I. pes-caprae and support, at least in part the traditional use of this plant for the treatment of dolorous processes (Krogh et al., 1999).

I. pes-caprae exhibited insulinogenic, hypoglycemic (Khan et al., 1994), anti-haemolytic (Pongprayoon et al., 1991a) antispasmodic (Pongprayoon et al., 1989; 1992a), antiinflammatory (Pongprayoon et al., 1992b) and anti-histamine (Wasuwat, 1970) activities.

The crude extract of $I$. pes-caprae reversibly inhibited the contractions induced by several spasmogens in a concentration-dependent manner (Pongprayoon et al., 1989). Bioassay guided fractionation of this extract resulted in isolation of the isoprenoids $E$-phytol and $\beta$-damascenone. The antispasmodic potencies of these compounds were found to be in the same range as that of papaverine, a known spasmolytic agent (Pongprayoon et al., 1992a). However, similar study with the plant collected in Brazil showed differece in terms of the chemical composition and did not showed antispasmodic activity when tested on isolated guineapig ileum and rat duodenum (Emendorfer et al., 2005).

From the leaves of $I$. pes-caprae were isolated the isochlorogenic acids a, b and c (24-26) which were also found in other species of Ipomoea, such as I. batatas and $I$. aquatica whose biological activities already were described. Beyond that, others quinic acid esters (2832) were also isolated from the leaves of this species (Teramachi et al., 2005). Isochlorogenic acids a, b and c (24-26) as well the quinic acid esters (28-32) presented collagenase inhibitory activity and showed almost no citotoxicity (Teramachi et al., 2005). The development of compounds with collagenase inhibitory activity is an effective method for preventing aging of the skin. During ageing occurs reduction of the collagen of the skin due to its decomposition by action of the enzyme called colagenase. Compounds that inhibit this enzyme will avoid then the reduction of the collagen and consequently will maintain elasticity of the skin (Teramachi et al., 2005).

I. pes-caprae showed to be clinically effective toward dermatitis caused by venomous jellyfishes (Wasuwat, 1970). The crude extract of this plant showed an inhibitory effect on prostaglandin synthesis in vitro. Bioassay-guided separation of the extract led to the isolation of four active compounds: 3,4-dihydro8-hydroxy-3-methyl-isocoumarin (40), eugenol (41), 4,4,7-trimethyl-1,4-dihydro-2-hydroxy-1-naftalenone (42) and 4-vinyl-guaiacol (43). The influence of these compounds on the formation of prostaglandins may partly explain a previously observed anti-inflammatory effect of the crude extract of I. pes-caprae (Pongprayoon et al., 1991b.) and supports the popular use of this plant to cure inflammations (Souza et al., 2000).

The cytotoxic potential of six lipophilic glycosides isolated from the aerial parts of $I$. pescaprae, namely, pescaproside A (86), pescapreins
I-IV (87-90) and the known stoloniferin III was evaluated against four human cancer cell lines. All compounds exhibited weak cytotoxicity (ED50 5-20 $\mu \mathrm{g} / \mathrm{mL}$ ) against nasopharyngeal (KB), colon (HCT15), squamous cell cervical (SQC-1 UISO) and ovarian (OVCAR) carcinomas (Pereda-Miranda et al., 2005). From flowers of $I$. pes-caprae were isolated three linear hetero-pentasaccharides of jalapinolic acid, pescapraeins XVIII-XX, which displayed resistancemodifying activity against strains of Staphylococcus aureus possess multidrug efflux pumps (EscobedoMartínez et al., 2010). The thin layer chromatography for the hydroethanolic solutions indicated the presence of isoquercitrin, being more evident from the leaves (Barni et al., 2009).

\section{Ipomoea purga}

The $\mathrm{CHCl}_{3}$ and $\mathrm{MeOH}$ extracts of $I$. purga showed a significant inhibitory effect (ED50 $<4 \mu \mathrm{g} / \mathrm{mL})$ against the human nasopharingeal carcinoma and breast cancer cell cultures (Pereda-Miranda \& Bah, 2003). The resin of $I$. purga of strong purgative effect is known as jalapa and consists of two fraction, one insoluble in ether called convolvulin and other soluble called jalapin (Costa, 2002). Treatment of convolvulin with sodium methoxide has yielded a $\beta$-D-quinovoside. It consist of one molecule of D-quinovose glycosidically linked to molecule of methyl 11-hydroxytetradecanoate (Singh \& Stacey, 1973). Alkaline hydrolysis of jalapin yields volatile acids, tyglic, acetic, propionic, isobutiric, isovaleric, valeric and methylethyl-acetic, beside jalaponic acid. It by acid hydrolysis yields the oses glucose, fucose and rhamnose, as well as, jalapinolic acid or 11-hydroxypalmitic acid (Costa, 2002).

\section{Ipomoea purpurea (L.) Roth.}

A glycoresin called ipopurpuroside was isolated from I. purpurea. It consists of glucose, rhamnose and 6-deoxy-D-glucose glycosidically linked to ricinoleic acid. The acyl group removed by alkaline hydrolysis was identified as methylbutyric acid (Navarro-Ruiz et al., 1978). Others glycoresins called marubajalapins I-XV were isolated from the jalapin fraction of the serial part (leaves and stems) of Pharbitis purpurea (I. purpurea) (Ono et al., 1992b). From the flowers of this species were isolated cyanidins and pelargonidins (Saito et al., $1995 ; 1996 ; 1998)$. The compound 3-O-(2-O-(6-O-Ecaffeoyl- $\beta$-D-glycopyranosyl))-(6-O-E-caffeoyl)- $\beta$-Dglycopyranosyl)-5-O- $\beta$-D-glycopyranoside-cianidin (46), also isolated from I. batatas and I. asarifolia, showed antioxidant activity (Kano et al., 2005). In study for investigation of new souces of ergoline alkaloids within the genus Ipomoea, I. purpurea was alkaloid-negative 
species, although previous reports indicated presence of ergoline alkaloids. Maybe because I. purpurea is often confused with $I$. tricolor an alkaloid-positive species (Amor-Prats \& Harborne, 1993b).

\section{Ipomoea squamosa Choisy}

From the leaves of I. squamosa were isolated the glycoresins called ipomoeassins A-E (59- 63). All the isolates showed citotoxic activity against human ovarian (A2780) cancer cell line. Ipomoeassins A-C and E were moderately active (IC50 from 0.5 to $3.3 \mu \mathrm{M}$ ). While Ipomoeassin D (62) (IC50 0,035 $\mu \mathrm{M}$ ) which differs from C (61) (IC50 2,9 $\mu \mathrm{M}$ ) only by an acetyl group, is almost two orders of magnitude more active than C. However, the derivative fully acetylated was less active. These observations suggest that relatively minor structural variations may make significant differences to cytotoxicity (Cao et al., 2005).

\section{Ipomoea stans Cav.}

This specie is known as tumbavaquero in Mexico. Study realized in rats with aqueous extract from the roots of $I$. stans indicated the presence of active substances which can exert a vasorelaxant effect, making them possibly effective for the treatment of clinical disturbances where high smooth muscle tension is the main symptom. This study supports the popular use of $I$. stans as an antispasmodic agent (Perusquia et al., 1995). Other study demonstrated anticonvulsant effect of aqueous, hydroalcohol and chloroform extracts from I. stans root in rats (Gonzalez Ramirez et al., 1985). $\mathrm{MeOH}$ extract of $I$. stans showed high antioxidative activity in the tests of inhibition of autoxidation, DPPH scavenging activity, and superoxide anion-scavenging activity (Choi et al., 1998). Ethyl acetate extract from Ipomoea stans roots showed central nervous system depressant activity (Herrera-Ruiz et al., 2007).

From a fraction of $I$. stans, with pronounced cytotoxicity towards three human tumor cell lines and with specific antibiotic activity against two bacterial strains, were isolated and identified three glycoresins fraction (Reynolds et al., 1995). In other study, were isolated from the roots of $I$. stans the glycoresins called stansins 1-5. These compounds were subjected to a cytotoxic assay using cultured cells representative of colon (HCT-15) cervical (UISO-SQC-1) and ovarian (OVCAR-5) carcinomas. Among these compounds, to be detached, stansin 5 (92) that presents citotoxic activity against ovarian (ED50 1,5 $\mathrm{gg} / \mathrm{mL}$ ) and cervical (ED50 4,0 $\mu \mathrm{g} / \mathrm{mL}$ ) carcinomas (León et al., 2004). Others glycoresins also isolated of $I$. stans were scammonic acid A and orizabin XX (Enriquez et al., 1992). But its biological activities were not reported. The coumarin scopoletin (34) was also isolated from roots of I. stans (Noda et al., 1994).

Ipomoea stolonifera (Cirillo) J.F. Gmel. (I. imperati (Vahl) Griseb.)

Methanol-water extract from the leaves of $I$. stolonifera (I. imperati Vahl Griseb.) showed local and systemic anti-inflammatory actions in mice and rats, respectively. This extract also presented antispasmodic activity on the isolated ileum, inhibiting histamine and acetylcholine. In the acute toxicity assay, $1 \mathrm{mg} / \mathrm{kg}$ of $I$. imperati methanol-water extract caused no mortality in mice after $24 \mathrm{~h}$ (Paula et al., 2003). From the ether-soluble resin glycoside fraction was isolated twelve glycoresins called stoloniferins I-XII were isolated in the pure state from the whole plants of I. stolonifera, but its biological activities were not reported (Noda et al., 1994; 1998).

\section{Ipomoea stolonifera (Cirillo) J.F. Gmel.}

From the ether-soluble resin glycoside fraction was isolated twelve glycoresins called stoloniferins I-XII were isolated in the pure state from the whole plants of $I$. stolonifera, but its biological activities were not reported (Noda et al., 1994; 1998).

\section{Ipomoea subincana Meisn.}

The results obtained showed that I. subincana is a potential source of bioactive compounds with immunosuppresive activity since the fractions 1 and 9 isolated from chloroform extract exhibited respectively 93,18 and $91,21 \%$ of nitric oxide Inhibition and respectively 98,69 e $53,90 \%$ of lymphoproliferation inhibition. The fractions 8 and 9 from chloroform extract were strongly lethal towards brine shrimp nauplii since exhibited LC50 respectively of 9,3 and $43,0 \mathrm{mg} / \mathrm{L}$. The fraction 6 from the ethyl acetate extract showed $49,6 \%$ of antioxidant activity surpassing the activity of the standard commercial antioxidant, galato de propila $(39,6 \%)$. From the chloroform extract of aerial parts of I. subincana were isolated scopoletin (34) and methyl 3,5-di- $O$-E-caffeoylquinate (32) whose biological activities already were described. Besides others compound as lupeol, $\beta$-sitosterol, vanillin, vanillic acid, aromadendrane-4 $\beta, 10 \alpha$-diol, $\quad 3$ - $\beta$ - $O$ - $\beta$-D-glycopiranosyl-sitosterol, cinamic acid, methyl caffeate, ethyl caffeate, methyl-3,4-dimethoxycinnamate, stigmasterol, $\alpha$-amyrin, $\beta$-amyrin, trans $n$-icosyl- $p$-coumarates, cis $n$-docosyl-p-coumarates, trans $n$-nonadecyl $p$-coumarates, trans $n$-henicosyl $p$-coumarates, 
trans- $n$-docosyl- $p$-coumarates, $\quad$ trans- $n$-tricosyl- $p$ coumarates, tyrosol and the novel glycolipid subincine and the new ceramides $\left(2 \mathrm{~S}^{*}, 2^{\prime} \mathrm{R}^{*}, 3 \mathrm{~S}^{*}, 4 \mathrm{R} *, 11 E\right)$ $N$-(2' -hydroxyhenicosanoyl)-2-amino-nonadec11-ene-1,3,4-triol (2S*,2' $\left.\mathrm{R}^{*}, 3 \mathrm{~S}^{*}, 4 \mathrm{R} *, 8 \mathrm{E}\right)-N-\left(2^{\prime}\right.$ hydroxytricosanoyl)-2-amino-nonadec-8-ene-1,3,4triol, whose biological activities not were determined. From the ethyl acetate extract were isolated quercetin, 3-O$\beta$-D-glycopiranosyl-quercetin, methyl 4-O-E-feruloyl-5$O$-E-caffeoyl-quinate and methyl 3,5-di-O-E-caffeoylquinate (32) (Meira et al., 2008; Meira, 2008).

\section{Ipomoea tyrianthina Lindl.}

From this specie were isolated tyrianthins A and B two new partially acylated glycolipid estertype heterodimers which showed significant in vitro relaxant effect on aortic rat rings. Scammonic acid A was determined as the glycosidic acid in both monomeric units. Also, these compounds were able to increase the release of GABA and glutamic acid in brain cortex, and displayed weak antimycobacterial activity (León-Rivera et al., 2009).

\section{Ipomoea tricolor Cav.}

The chloroform extract of $I$. tricolor showed effective chemical property for suppressing the growth of other plants. Bioactivity-directed fractionation of the crude extracts of $I$. tricolor led to the identification of the glycoresins mixture as the active fraction. Further chromatographic analysis of this fraction yielded tridolorin A (93) as the main constituent responsible for the phytotoxicity (Pereda-Miranda \& Bah, 2003; Bah \& Pereda-Miranda, 1996; Pereda-Miranda et al., 1993). Tricolorin A (93) showed antimicrobial activity against Staphylococcus aureus and strong citotoxic activity against human breast cancer (ED50 2,2 $\mu \mathrm{g}$ / $\mathrm{mL}$ ). All member of the tricolorin series (tricolorin A-J) (93-102) exhibited a weak cytotoxicity against colon carcinoma, squamous cell cervix carcinoma and ovarium cancer cell lines (ED50 4-20 $\mu \mathrm{g} / \mathrm{mL}$ ). But a stronger effect was observed agains oral epidermoid carcinoma (KB, ED50 1-5 $\mu \mathrm{g} / \mathrm{mL}$ ) (Pereda-Miranda \& Bah, 2003).

From I. tricolor were isolated several ergoline alkaloids such as, agroclavine (1), chanoclavine I (2), elymoclavine (3), ergine (4), ergocristine (6), ergotamine (7), ergometrine (8), penniclavine (12), besides, dihydrolysegol, isolysergol, ergometrinine, ergostine, and noragroclavine (Botz et al., 1991; Hahn, 1990). Althought all of the natural ergoline alkaloids increase the motor activity of the uterus; ergometrine (8) is most active and also less toxic than ergotamine (7). Ergotamine (7) presents also vasoconstritor activiy and is useful in the treatment of migraine headaches (Madlom, 2002).

Coumarin (33) and scopoletin (34) were also isolated of this species (Shah et al., 1972). The biological activity of scopoletin, also found in I. batatas, I. cairica and I. digitata, already were described. The coumarin (33) presents antiedema properties and is also imunoestimulant and exhibit citotoxic activity (Bruneton, 2001).

\section{Ipomoea violacea $\mathrm{L}$.}

From I. violacea were isolated several ergoline alkaloids, such as, chanoclavine I (2), elymoclavine (3), egine (4), erginine (5), ergometrine (8), lysergol (11), penniclavine (12), besides, chanoclavine II and ergometrinine (Stanescu et al., 1973; Weber \& Ma, 1976). The main ergoline alkaloid in the seeds of $I$. violacea is ergine (4). The total alkaloid content of $I$. violacea seed is approximately five times as great as that of the seeds of I. corymbosa (Rivea corybosa) (Hoffmann, 1971). Calystegins B1 (16) and C1 (18) were also isolated of this species (Schimming et al., 1998).

\section{Conclusion}

The plants of the genus Ipomoea have long been used in folk medicine for the treatment of a wide variety of pathological conditions, including their use to treat inflammatory and algesic processes, kidney ailments, constipation, colic and digestive disorders. In recent years, the scientific interest in plants of Ipomoea genus has increased greatly. Substantial progresses on chemistry and pharmacological properties of this genus have showed it. Some species showed antimicrobial, analgesic, spasmolitic, spasmogenic, hypotensive, psychotomimetic and anticancer activities. Pharmacological studies have confirmed some uses in folk medicine. For example, antinociceptive action of $I$. pes-caprae that supported, at least in part, the traditional use of this plant for the treatment of dolorous processes. Other study realized in rats with aqueous extract from the roots of I. stans indicated the presence of active substances which can exert a vasorelaxant effect confirming the popular use of $I$. stans as an antispasmodic agent. Although, an extensive amount of research work has been done on some plants of genus Ipomoea to date, a large number of species are still partially studied such as, $I$. parasitica, I. operculata (syn. Operculina macrocarpa), I. lonchophylla, I. involucrata, I. hederacea, I. bahiensis. Consequently, a broad field of future research remains possible in which the isolation of new active principles from these species would be of great scientific merit. Glycolipds, phenolics compounds and alkaloids are of particular interest as many are highly potent bioactives and perhaps responsible for most of activities 
shown by the plants of this genus. A detailed study is required to understand the structure-activity relationship of these constituents. Many plant extracts of Ipomoea showed biological activity. However, the particular constituent responsible for the activity has not always been isolated in further process. Furthermore, some plant extracts were only preliminarly studied for their in vitro activities, so, the advance clinical trial of them deserves to be further investigated.

\section{References}

Abbott I A, Shimazu C 1985. The geographical origin of plants most commonly used for medicine by Hawaiians. $J$ Ethnopharmacol 14: 213-222.

Abou-Chaar CI 1967. Alkaloids of an Ipomoea seed. Lebanese Pharm J 9: 93-109.

Amor-Prats D, Harborne JB 1993a. Allelochemical effects of ergoline alkaloids from Ipomoea parasitica on Heliothis virescens. Birkhäuser Verlag AG 4: 55-61.

Amor-Prats D, Harborne JB 1993b. New sources of ergoline alkaloids within the genus Ipomoea. Biochem Syst Ecol 21: 455-461.

Asano N, Yokoyama K, Sakurai M, Ikeda K, Kizu H, Kato A, Arisawa M, Höke D, Dräger B, Watson AA, Nash RJ 2001. Dihydroxynortropane alkaloids from calystegine-producing plants. Phytochemistry 57: 721-726.

Austin DF 1997. Convolvulaceae (morning glory family). http:// ag.arizona.edu/herbarium/assoc/people/daustin/convolv. html, acessed May 2011.

Austin DF, Huáman Z 1996. A synopsis of Ipomoea (Convolvulaceae) in the Americas. Taxon 45: 3-38.

Baek NI, Ahn EM, Bang MH, Kim HY 1997. Development of biologically active compounds from edible plant sources - I. Isolation of major components from the tuber of Ipomoea batatas Lam. Han'guk Nonghwa Hakhoechi 40: 583-587.

Bah M, Pereda-Miranda R 1996. Detailed FAB-mass spectrometry and high resolution NMR investigations of tricolorin A-E, individual oligosaccharides from the resins of Ipomoea tricolor (Convolvulaceae). Tetrahedron 52: 13063-13080.

Bah M, Pereda-Miranda R 1997. Isolation and structural characterization of new ester type dimers from the resin of Ipomoea tricolor (Convolvulaceae). Tetrahedron 53: 9007-9022.

Barbosa-Filho JM, Athayde-Filho PF, Silva PMS, Agra MF, Bhattacharyya J 1996. Constituents of Ipomoea horrida Humber ex Ducke: spectroscopic identification of the flavonoids. Rev Bras Farmacogn 5: 161-166.

Barnes CC, Smalley MK, Manfredi KP, Kindscher K, Loring H, Sheeley DM 2003. Characterization of an antituberculosis resin glycoside from the Prairie medicinal plant Ipomoea leptophylla. J Nat Prod 66: 1457-1462.

Barni ST, Cechinel-Filho V, Couto AG 2009. Caracterização química e tecnológica das folhas, caules e planta inteira da Ipomoea pes-caprae (L.) R. Br., Convolvulaceae, como matéria-prima farmacêutica. Rev Bras Farmacogn
19: $865-870$

Belkin M, Fitzgerald DB, Cogan GW 1952. Tumor-damaging capacity of plant materials. I. Plants used as cathartics. $J$ Natl Cancer I 13: 139-55.

Bieber LW, Silva Filho AA, Lima RMOC, Chiappeta AA, Nascimento SC, Souza IA, Méllo JF, Veith HJ 1986. Anticancer and antimicrobial glycosides from Ipomoea bahiensis. Phytochemistry 25: 1077-1081.

Botz L, Hahn E, Szabo LG 1991. Botanical identification of Ipomoea tricolor Cav. seed samples from Hungary and thin-layer chromatographic examination of their hallucinogen ergot alkaloids. Acta Bot. Hung 36: 229243.

Bovell-Benjamin AC 2007. Sweet Potato: A review of its past, present, and future role in human nutrition. Adv Food Nutr Res 52: 1-59.

Boyd MR, Wilson BJ 1972. Isolation and characterization of 4-ipomeanol, a lung-toxic furanoterpenoid by sweet potatoes (Ipomoea batatas). J Agric Food Chem 20: 428430.

Bruneton J 2001. Farmacognosia, fitoquímica,plantas medicinais. 5 ed. Zaragoza: Editorial Acribia S.A.

Camargo MTLA 1998. Contribuição ao estudo da Ipomoea purpurea Roth., I. alba L. e I. pes-caprae Sw. empregadas na medicina popular e em rituais de religiões de origem e influência africana no Brasil. VI Simpósio Argentino de Farmacobotanica. I Reunion de Farmacobotanica de Paises integrantes del Mercosur Posadas, Missiones, Argentina. http:// www.qui.una.py/botanicafcq/Vol\%205(1)\%201999/ Contribuicao\%20ao\%20estudo.pdf, acessed 20 May 2011.

Cambie RC, Ferguson LR 2003. Potential functional foods in the traditional Maori diet. Mutat Res: 109-117, 523524.

Cao S, Guzza RC, Wisse JH, Miller JS, Evans R, Kingston DGI 2005. Ipomoeassins A-E, cytotoxic macrocyclic glicoresins from the leaves of Ipomoea squamosa from the Suriname rainforest. J Nat Prod 68: 487-492.

Chaudhary SS, Singh H, Handa KL 1957. Chemical composition of Ipomea palmata and pharmacollogy of its extracts. Curr Sci 26: 148-149.

Chen X, Chu Y 1998. Inhibitory effects of ipalbidine on respiratory burst and oxygen free radicals of leukocytes. Zhongguo Yaolixue Tongbao 14: 243-244.

Chérigo L, Pereda-Miranda R, Gibbons S 2009. Bacterial resistance modifying tetrasaccharide agents from Ipomoea murucoides. Phytochemistry 70: 222-227.

Cho MK, Jang YP, Kim YC, Kim SG 2004. Arctigenin, a phenylpropanoid dibenzylbutyrolactone lignan, inhibits MAP kinases and AP-1 activation via potent MKK inhibition: the role in TNF-alpha inhibition. Int Immunopharmacol 10-11: 1419-1429.

Choi WS, Lee SE, Lee HS, Lee YH, Park BS 1998. Antioxidative activities of methanol extracts of tropical and oriental medicinal plants. Han'guk Nonghwa Hakhoechi 41: 556-559.

Costa AF 2002. Farmacognosia. v. II, 5. ed. Lisboa: Fundação Calouste Gulbenkian.

Dai H, Xiong J, Zhou J, Ding Z 2000. Chemical constituents from root of Ipomoea digitata. Yunnan Zhiwu Yanjiu 


\section{2: $166-168$}

Daló N, Moussatché H 1978. Acción tóxica de las plantas del género Ipomoeas. Tarea Común. Rev Universidad Centro Occidental 6: 25-39.

Dawidar AM, Winternitz F, Johns SR 1977. Structure of ipomine, a new alkaloid from Ipomoea muricata Jacq. Tetrahedron 33: 1733-1734.

De Balogh KIM, Dimande AP, Van Der Lugt JJ, Molyneux RJ, Naudé TW, Welman WG 1999. A lysosomal storage disease induced by Ipomoea carnea in goats in Mozambique. J Vet Diagn Invest 11: 266-273.

Der Marderosian A, Cho E, Chao JM 1974. Isolation and identification of ergoline alkaloids from Ipomoea muelleri. Planta Med 25: 6-16.

Der Marderosian AH, Youngken Jr HW 1966. The distribution of indole alkaloids among certain species and varieties of Ipomoea, Rivea, and Convolvulus. Lloydia 29: 35 42.

Dewick PM 2002. Medicinal Natural Products. A Byosynthetic Approach. 2. ed. New York:John Wiley \& Sons Ltda.

Diaz JL 1976. Uso de las Plantas Medicinales de Mexico. Monografias Cientificas II. IMEPLAN, Mexico D.F., Mexico, pp. 31, 56-57, 67, 69, 118.

Dini I, Tenore GG, Dini A 2009. Saponins in Ipomoea batatas tubers: Isolation, characterization, quantification and antioxidant properties. Food Chem 113: 411-419.

Duke JA, Wain KK 1981. Medicinal Plants of the World, 3 vol. Computer index with more than 85,000 entries. Plants genetics and germplasm Institute. Agriculture Research Service, Beltsville, Maryland.

Ehattacharya SK, Ray A 1975. Dasgupta, B. Central Nervous System depressant activity of Ipomoea carnea Jacq. Indian J Pharmac 7: 31-34.

Eich E, Pertz H, Kaloga M, Schulz J, Fesen MR, Mazumder A, Pommier Y 1996. (-)-Arctigenin as a lead structure for inhibitors of human immunodeficiency virus type-1 integrase. J Med Chem 39: 86-95.

Ejimadu IM, Ogbeide ON 2001. Antimicrobial activities of petroleum ether and ethanol extracts of leaf, stem and root barks of Ipomoea involucrata P. Beauv. J Chem Soc Nigeria 26: 56-59.

Emendorfer F, Emendorfer F, Bellato F, Noldin V F, Niero R, Cechinel-Filho V, Cardozo AM 2005. Evaluation of the relaxant action of some Brazilian medicinal plants in isolated guinea-pig ileum and rat duodenum. J Pharm Pharmaceut Sci 8: 63-68.

Enriquez RG, Leon I, Perez F, Walls F, Carpenter KA, Puzzuoli FV, Reynolds WF 1992. Characterization, by two-dimensional NMR spectroscopy, of a complex tetrasaccharide glycoside isolated from Ipomoea stans. Can J Chem 70: 1000-1008.

Escobedo-Martínez C, Cruz-Morales S, Fragoso-Serrano M, Rahman MM, Gibbons S, Pereda-Miranda R 2010. Characterization of a xylose containing oligosaccharide, an inhibitor of multidrug resistance in Staphylococcus aureus, from Ipomoea pes-caprae. Phytochemistry 71: 1796-1801.

Exconde NC, Guevara BQ, Lerma JV, Nonato MG, Sibulo M, Solevilla RC, Songco LV 2004. An antibacterial and analgesic drug material from Tonkin. Project from HERDIN Central Hub.
Ferrari G 1979. Steroid polyhydroxylates, lysergol, and ergolinic alkaloids. Ger. Offen. DE 78-2834703 19780808

Ferreira AA, Amaral FA, Duarte IDG, Oliveira PM, Alves RB, Silveira D, Azevedo AO, Raslan DS, Castro MSA 2006. Antinociceptive effect from Ipomoea cairica extract. $J$ Ethnopharmacol 105: 148-153.

Ghani A 1989. Medicinal Plants of Bangladesh. Published by Asiatic Society of Bangladesh, 201 pp.

Gilmore M 1977. Uses of Plants by Indians of the Missouri River Region. University of Nebraska Press: Lincoln. NB.

Goda Y, Shimizu T, Kato Y, Nakamura M, Maitani T, Yamada T, Terahara N, Yamaguchi M 1997. Two acylated anthocyanins from purple sweet potato. Phytochemistry 44: 183-186.

Gonzalez Ramirez D, Hernandez RM, Bolado C, Garcia Delgado J 1985. Possible anticonvulsant activity of the root of Ipomoea stans. Salud pública de México 27: 485-491.

Górniak S, Gotardo A, Pfister J 2010. The effects of Ipomoea carnea on neonate behavior: A study in goats. Toxicol Lett 196: S186.

Gorzalczany S, Acevedo C, Muschietti L, Martino V, Ferraro G 1996. Search for antiinflammatory activity in Argentine medicinal plants. Phytomedicine 3: 181-184.

Gourley JM, Heacock RA, Mcinnes AG, Nikolin B, Smith DG 1969. Structure of ipalbine, a new hexahydroindolizine alkaloid isolated from Ipomoea alba. J Chem Soc 13: 709-710.

Guan Y, Wu T, Lin M, Lin M, Ye J 2006. Determination of pharmacologically active ingredients in sweet potato (Ipomoea batatas) by capillary electrophoresis with electrochemical detection. J Agric Food Chem 54: 2428.

Hahn E 1990. Qualitative and quantitative examination of lysergic acid derivatives in Ipomoea species. Gyogyszereszet 34: 349-358.

Halpern JH 2004. Hallucinogens and dissociative agents naturally growing in the United States. Pharmacol Ther 102: 131-138.

Haraguchi M, Gorniak SL, Ikeda K, Minami Y, Kato A, Watson AA, Nash RJ, Molyneux RJ, Asano N 2003. Alkaloidal components in the poisonous plant, Ipomoea carnea (Convolvulaceae). J Agric Food Chem 51: 4995-5000.

Hernandez-Carlos B, Bye R, Pereda-Miranda R 1999. Orizabins V-VIII, tetrasaccharide glycolipids from the Mexican scammony root (Ipomoea orizabensis). J Nat Prod 62: 1096-1100.

Herrera-Ruiz M, Gutiérrez C, Jiménez-Ferrer JE,Tortoriello J, Mirón G, León I 2007. Central nervous system depressant activity of an ethyl acetate extract from Ipomoea stans roots. J Ethnopharmacol 112: 243-247.

Hoffmann A 1963. The active principles of the seeds of Rivea corymbosa and Ipomoea violacea. Harvard Univ Bot Mus Leafl 20: 194-212.

Hoffmann A 1971. Teonanácatl and Ololiuqui, two ancient magic drugs of Mexico. B Narcotics 1: 3-14.

Hoffmann A, Cerletti A 1961. Active substances in the third aztec magic drug. The solution to the ololiuqui puzzle. Deut Med Wochenschr 86: 885-888. 
Hoffmann A, Tscherter H 1960. Isolation of lysergic acid alkaloid from the Mexican magic drug Ololuiqui (Rivea corymbosa). Sandoz Lab., Basel, Switz. Experientia 16: 414-416.

Honda T, Namiki H, Nagase H, Mizutani H 2003. Total synthesis of an indolizidine alkaloid, (+)-ipalbidine, by means of an intramolecular McMurry coupling reaction. Arkivoc VIII: 188-198.

Hueza IM, Fonseca ES, Paulino CA, Haraguchi, M., Gorniak SL 2003a. Evaluation of immunomodulatory activity of Ipomoea carnea on peritoneal cells of rats. $J$ Ethnopharmacol 87: 181-186.

Hueza IM, Dagli ML, Gorniak SL, Paulino CA 2003b. Toxic effects of prenatal Ipomoea carnea administration to rats. Vet Hum Toxicol 45: 298-302.

Hueza IM, Guerra JL, Haraguchi M, Asano N, Górniak SL 2005. The role of alkaloids in Ipomoea carnea toxicosis: A study in rats. Exp Toxicol Pathol 57: 53-58.

Ikeda K, Kato A, Adachi I, Haraguchi M, Asano N 2003. Alkaloids from the poisonous plant Ipomoea carnea: effects on intracellular lysosomal glycosidase activities in human lymphoblast cultures. J Agric Food Chem 51: $7642-7646$

Ikhiri K, Koulodo DDD, Garba M, Mamane S, Ahond A, Poupat C, Potier P 1987. New indolizine alkaloids from Ipomoea alba. J Nat Prod 50: 152-156.

Islam MS, Yoshimoto M, Yahara S, Okuno S, Ishiguro K, Yamakawa O 2002a. Identification and characterization of foliar polyphenolic composition in sweetpotato (Ipomoea batatas L.) genotypes. J Agric Food Chem 50: 3718-3722.

Islam MS, Yoshimoto M, Terahara N, Yamakawa O 2002b. Anthocyanin composition in sweetpotato (Ipomoea batatas L.) leaves. Biosci Biotechnol Biochem 66: 24832486.

Islam S, Yoshimoto M, Ishiguro K, Yamakawa O 2003. Bioactive compounds in Ipomoea batatas leaves. Acta Hortic 2: 693-699.

Jayaweera DMA 1982. In: Medicinal plants (indigenous and exotic) used in Ceylon. Part 11, National Science Council, Colombo, Sri Lanka, 99 pp.

Jenett-Siems K, Kaloga M, Eich E 1993. Ipangulines, the first pyrrolizidine alkaloids from the Convolvulaceae. Phytochemistry 34: 437-440.

Jenett-Siems K, Schimming T, Kaloga M, Eich E, Siems K, Gupta MP, Witte L, Hartmann T 1998. Pyrrolizidine alkaloids of Ipomoea hederifolia and related species. Phytochemistry 47: 1551-1560.

Jenett-Siems K, Weigh R, Kaloga M, Schulz J, Eich E 2003. Ipobscurines $\mathrm{C}$ and $\mathrm{D}$ : macrolactam-type indole alkaloids from the seeds of Ipomoea obscura. Phytochemistry 62: 1257-1263.

Jenett-Siems K, Kaloga M, Eich E 2004. Ergobalansine/ ergobalansinine, a proline-free peptide-type alkaloid of the fungal genus Balansia, is a constituent of Ipomoea piurensis. (Erratum to document cited in CA121:297184). J Nat Prod 67: 2160.

Kaneshiro T, Suzui M, Takamatsu R, Murakami A, Ohigashi H, Fujino T, Yoshimi N 2005. Growth inhibitory activities of crude extracts obtained from herbal plants in the Ryukyu Islands on several human colon carcinoma cell lines. Asian Pacific J Cancer Prev 6: 353-358.

Kang SY, Sung SH, Park JH, Kim YC 1998. Hepatoprotective activity of scopoletin, a constituent of Solanum lyratum. Arch Pharmacal Res 21: 718-722.

Kano M, Takayanagi T, Harada K 2005. Antioxidative activity of anthocyanins from purple sweet potato, Ipomoera batatas cultivar ayamurasaki. Biosci Biotechnol Biochem 69: 979-988.

Khan MM, Ahmad F, Rastogi AK, Kidwai JR 1994. Insulinogenic and hypoglycemic activities of Ipomoea pes-caprae. Fitoterapia 65: 231-234.

Kilham C 2004. Tamanu oil: a tropical topical remedy. Herbalgram 63: 26-31.

Ko SG, Koh SH, Jun CY, Nam CG, Bae HS, Shin MK 2004. Induction of apoptosis by Saussurea lappa and Pharbitis nil on AGS gastric cancer cells. Biol Pharm Bull 27: 1604-1610.

Krauss J, Unterreitmeier D 2005. Synthesis of new lipophilic ipomeanol analogues and their cytotoxic activities. Arch Pharm (Weinheim Ger) 338: 44-48.

Krogh R, Kroth R, Berti C, Madeira AO, Souza MM, CechinelFilho V, Delle-Monache F, Yunes RA 1999. Isolation and identification of compounds with antinociceptive action from Ipomoea pes-caprae (L.) R. Br. Die Pharmazie 54: 464-466.

Kusano S, Abe H 2000. Antidiabetic activity of white skinned sweet potato (Ipomoea batatas L.) in obese Zucker fatty rat. Biol Pharm Bull 23: 23-26.

Kusano S, Abe H, Okada A 1998. Study of antidiabetic activity of white skinned sweet potato (Ipomoea batatas L.): comparation of normal and streptozotocin induced diabetic rats and hereditary diabetic mice. Nippon Nougeikagaku kaishi (in Japanese) 72: 1045-1052.

Kusano S, Abe H, Tamura H 2001. Isolation of antidiabetic Components from White-skinned Sweet Potato (Ipomoea batatas L.). Biosci Biotechnol Biochem 65: 109-114.

Lamidi M, Rondi ML, Ollivier E, Faure R, Ekekang LN, Balansard G 2000. Constituents of Ipomoea fistulosa leaves. Fitoterapia 71: 203-204.

Lee JH, Lee KT, Yang JH, Baek NI, Kim DK 2004. Acetylcholinesterase inhibitors from the twigs of Vaccinium oldhami Miquel. Arch Pharmacal Res 27: 5356.

Lee L, Cheng E, Rhim J, Ko B, Choi S 1997. Isolation and identification of anthocyanins from purple sweet potatoes. J Food Sci Nutr 2: 83-88.

León I, Enríquez RG, Nieto DA, Alonso S, Reynolds WF, Aranda E, Villa J 2005. Pentasaccharide glycosides from the roots of Ipomoea murucoides. J Nat Prod 68: 1141-1146.

León I, Enríquez RE, Gnecco D, Villarreal ML, Cortés DA, Reynolds WF, Yu M 2004. Isolation and characterization of five new tetrasaccharide glycosides from the roots of Ipomoea stans and their cytotoxic activity. $J$ Nat Prod 67: 1552-1556.

León-Rivera I, Mirón-López G, Estrada-Soto S, Aguirre-Crespo F, Gutiérrez MC, Molina-Salinas GM, Hurtado G, Navarrete-Vázquez G, Montiel E 2009. Glycolipid estertype heterodimers from Ipomoea tyrianthina and their pharmacological activity. Bioorg Med Chem Lett 19: 4652-4656. 
Lima OOA, Braz-Filho R 1997. Dibenzylbutyrolactone lignans and coumarins from Ipomoea cairica. J Braz Chem Soc 8: 235-238

Liu XL, Zhang L, Fu XL, Chen K, Qian BC 2001. Effect of scopoletin on PC3 cell proliferation and apoptosis. Acta Pharmacol Sin 22: 929-933.

Locher CP, Burch MT, Mower HF, Berestecky J, Davis H, Van Poel B, Lasure A, Vanden Berghe DA, Vlietinck AJ 1995. Anti-microbial activity and anti-complement activity of extracts obtained from selected Hawaiian medicinal plants. J Ethnopharmacol 49: 23-32.

Lorenzi H, Abreu Matos FJ 2002. Plantas Medicinales no Brasil. Nativas e exóticas. Instituto Plantarum de Estudos da Flora Ltda. São Paulo.

Ludvik BH, Mahdjoobian K, Waldhaeusl W, Hofer A, Prager R, Kautzky-Willer A, Pacini G 2002. The effect of Ipomoea batatas (Caiapo) on glucose metabolism and serum colesterol in pacients with type 2 diabets. Diabetes Care 25: 239-240.

Ludvik B, Neuffer B, Pacini G 2004. Efficacy of Ipomoea batatas (Caiapo) on diabetes control in type 2 diabetic subjects treated with diet. Diabetes Care 27: 436440 .

Ludvik B, Waldhausl W, Prager R, Kautzky-Willer A, Pacini G 2003. Mode of action of Ipomoea batatas (Caiapo) in type 2 diabetic patients. Metabolism 52: 875-880.

Luo JG, Kong LY 2005. Study on flavonoids from leaf of Ipomoea batatas. Zhongguo Zhong Yao Za Zhi 30: 516-518.

Ma SC, Du J, But PPH, Deng XL, Zhang YW, Ooi VEC, Xu HX, Lee SHS, Lee SF 2002. Antiviral Chinese medicinal herbs against respiratory syncytial virus. $J$ Ethnopharmacol 79: 205-211.

Macleod JK, Ward A, Oelrichs PB 1997. Structural investigation of resin glycosides from Ipomoea lonchophylla. J Nat Prod 60: 467-471.

Madlom Z 2002. The Origin of Drugs in Current Use: The Ergot Alkaloids Story. http://www.world-of-fungi.org/Mostly Medical/Ziad_Madlom/Ergot_alkaloids.htm, acessed $2 \overrightarrow{5}$ May 2011.

Mahmood N, Moore PS, Tommasi ND, Simone FD, Colman S, Hay AJ Pizza C 1993. Inhibition of HIV infection by caffeoylquinic acid derivatives. Antiviral Chem Chemother 4: 235-240.

Malalavidhane S, Wickramasinghe SM, Jansz ER 2001. An aqueous extract of the green leafy vegetable Ipomoea aquatica is as effective as the oral hypoglycaemic drug tolbutamide in reducing the blood sugar levels of Wistar rats. Phytother Res 15: 635-637.

Malalavidhane TS, Wickramasinghe SM, Jansz ER 2000. Oral hypoglycaemic activity of Ipomoea aquatica. $J$ Ethnopharmacol 72: 293-298.

Mamun MM, Billah MM, Ashek MA, Ahasan MM, Hossain MJ, Sultana T 2003. Evaluation of diuretic activity of Ipomoea aquatica (Kalmisak) in mice model study. $J$ Med Sci 3: 395-400.

Martinez M 1989. Las Plantas Medicinais de Mexico. Mexico: Ediciones Botas.

Martinez M 1990. Las Plantas Medicinais de Mexico. Mexico: Ediciones Botas, p. 276-279.

Matin MA, Tewari JP, Kalani DK 1969a. Pharmacological effects of paniculatin-a glycoside isolated from Ipomoea digitata Linn. J Pharm Sci 58: 757-759.

Matin MA, Tewari JP, Kalani DK 1969b. Pharmacological investigations of Ipomea digitata. Indian J Med Sci 23: 479-482.

Matsui T, Ebuchi S, Kobayashi M, Fukui K, Sugita K, Terahara N, Matsumoto K 2002. Anti-hyperglycemic effect of diacylated anthocyanin derived from Ipomoea batatas cultivar ayamurasaki can be achieved through the $\alpha$-glucosidase inhibitory action. J Agric Food Chem 50: 7244-7248.

Medeiros RMT, Barbosa RC, Riet-Correa F, Lima EF, Tabosa IM, Barros SS, De Gardner DR, Molyneux RJ 2003. Tremorgenic syndrome in goats caused by Ipomoea asarifolia in Northeastern Brazil. Toxicon 41: 933-935.

Meira M 2008. Estudo fitoquímico das partes aéreas de Ipomoea subincana (Convolvulaceae). Salvador-BA, 212 p. Tese de Doutorado, Instituto de Química, Universidade Federal da Bahia.

Meira M, David JM, David JP, Araujo SV, Regis TL, Giulietti AM, Queiróz LP 2008. Chemical constituents of Ipomoea subincana Meisn. (Convolvulaceae). Quim. Nova 31: 751-754.

Minamikawa T, Akazawa T, Uritani I 1962. Isolation of esculetin from sweet potato roots with black rot. Nature (London $U K)$ 195: 726-727.

Miyahara MRM, Imamura PM, Freitas JC, Leonor SJ, Baffa O, Kinoshita A, Paula-Zurron ACB 2011. Anti-oxidative and anti-ulcerogenic activity of Ipomoea imperati. Rev Bras Farmacogn 21: 978-985.

Misra AL, Tewari JD 1953. Chemical examination of Ipomoea muricata seeds. IV. J Indian Chem Soc 30: 391-397.

Misra AL, Tewari JD 1952. Chemical examination of Ipomoea muricata seeds. II. J Indian Chem Soc 29: 63-67.

Mitscher LA, Telikepalli H 1992. Bioassay-directed discovery of natural product leads. Antibacterials and antifungals from unusual sources. Workshop 5: 281-310.

Miyazaki Y, Kusano S, Doi H, Aki O 2005. Effects on immune response of antidiabetic ingredients from white-skinned sweet potato (Ipomoea batatas L.). Nutrition 21: 358362.

Mori M, Yoshida K, Ishigaki Y, Matsunaga Y, Nikaido O, Kameda K, Kondo T 2005. UV-B protective effect of a polyacylated anthocyanin, HBA, in flower petals of the blue morning glory, Ipomoea tricolor cv. Heavenly Blue. Bioorg Med Chem 13: 2015-2020.

Nam KA, Lee SK 2000. Evaluation of cytotoxic potential of natural products in cultured human cancer cells. Nat Prod Sci 6: 183-188.

Navarro-Ruiz A, Mora GP de La, Villanueva-Michel MT, Dominguez-Rodriguez JR, Bastidas-Ramirez BE, Quezade-Arellano JD, Ruiz-Nikolin A, Nikolin B, Jankovi M 1978. Ipopurpuroside, a new glycoside from Ipomoea purpurea. Phytochemistry 17: 451-452.

Noda N, Nishi M, Ono M, Miyahara K, Kawasaki T 1985. Isolation and structures of the resin glycosides of Ipomoea orizabensis (roots) and I. muricata (seeds). Fac. Pharm. Sci., Setsunan Univ., Japan. Tennen Yuki Kagobutsu Toronkai Koen Yoshishu 27: 427-434.

Noda N, Ono M, Miyahara K, Kawasaki T 1987. Resin glycosides. I. Isolation and structure elucidation of 
orizabin I, II, III and IV. Genuine resin glycosides from the root of Ipomoea orizabensis. Tetrahedron 43: 38893902.

Noda N, Kobayashi H, Miyahara K, Kawasaki T 1988a. Resin glycosides. III. Isolation and structural study of the genuine resin glycosides, muricatins I-VI, from the seeds of Ipomoea muricata. Chem Pharm Bull 36: 920-929.

Noda N, Nishi M, Miyahara K, Kawasaki T 1988b. Resin glycosides. IV. Two new resin glycosides, muricatins VII and VIII, from the seeds of Ipomoea muricata. Chem Pharm Bull 36: 1707-1713.

Noda N, Kobayashi H, Miyahara K, Kawasaki T 1988c. Resin glycosides. II. Identification and characterization of the component organic and glycosidic acids of the crude resin glycoside from the seeds of Ipomoea muricata. Chem Pharm Bull 36: 627-633.

Noda N, Kogetsu H, Kawasaki T, Miyahara K 1990. Scammonins I and II, the resin glycosides of radix scammoniae from Convolvulus scammonia. Phytochemistry 29: 3565-3569

Noda N, Yoda S, Kawasaki T, Miyahara K 1992. Resin Glycosides. XV. Simonins I-V, ether-soluble resin glycosides (jalapins) from the roots of Ipomoea batatas (cv. Simon). Chem Pharm Bull 40: 3163-3168.

Noda N, Takahashi N, Kawasaki T, Miyahara K, Yang CR 1994. Stoloniferins I-VII, resin glycosides, from Ipomoea stolonifera. Phytochemistry 36: 365-371.

Noda N, Takahashi N, Miyahara K, Yang CR 1998. Stoloniferins VIII-XII, resin glycosides, from Ipomoea stolonifera. Phytochemistry 48: 837-841.

Odake K, Terahara N, Saito N, Toki K, Honda T 1992. Chemical structures of two anthocyanins from purple sweet potato, Ipomoea batatas. Phytochemistry 31: 2127-2130.

Okudaira R, Kyanbu H, Ichiba T, Toyokawa T 2005. Ipomoea extracts with disaccharidase-inhibiting activities. Jpn. Kokai Tokkyo Koho JP 2005213221.

Oliveira EJ, Romero MA, Silva MS, Silva BA, Medeiros IA. 2001. Intracellular calcium mobilization as a target for the spasmolytic action of scopoletin. Planta Med 67: 605-608

Ono M, Kubo K, Miyahara K, Kawasaki T 1989. Operculin I and II, new ether-soluble resin glycosides ("jalapin") with fatty acid ester groups from Rhizoma Jalapae Braziliensis (roots of Ipomoea operculata). Chem Pharm Bull 37: 241-244.

Ono M, Nishi M, Kawasaki T, Miyahara K 1990. Resin glycosides. IX. Operculins I, II, V, VII and VIII, new ether-soluble resin glycosides of Rhizoma Jalapae Braziliensis (the roots of Ipomoea operculata). Chem Pharm Bull 38: 2986-2991.

Ono M, Kawasaki T, Miyahara K 1991. Resin glycosides. XI. Operculins III, IV, IX, X, XVI, XVII and XVIII, new ether-soluble resin glycosides of rhizoma jalapae braziliensis (root of Ipomoea operculata). Chem Pharm Bull 39: 2534-2539.

Ono M, Fujimoto K, Kawata M, Fukunaga T, Kawasaki T, Miyahara K 1992a. Resin glycosides. XIII. Operculins VI, XI, XII, XIII, XIV and XV, the ether-soluble resin glycosides (jalapin) from Rhizoma Jalapae Braziliensis (roots of Ipomoea operculata). Chem Pharm Bull 40: $1400-1403$
Ono M, Ueguchi T, Murata H, Kawasaki T, Miyahara K 1992b. Resin glycosides. XVI. Marubajalapins I-VII, new ether-soluble resin glycosides from Pharbitis purpurea. Chem Pharm Bull 40: 3169-3173.

Pale E, Kouda-Bonafos M, Nacro M, Vanhaelen M, VanhaelenFastré R 2003. Two triacylated and tetraglucosylated anthocyanins from Ipomoea asarifolia flowers. Phytochemistry 64: 1395-1399.

Pale E, Nacro M, Vanhaelen M, Vanhaelen-Fastret R, Ottinger R 1998. Acylated anthocyanins from the flowers of Ipomoea asarifolia. Phythochemistry 48: 1433-1437.

Panaccione DG 2005. Origins and significance of ergot alkaloid diversity in fungi. FEMS. Microbiol Lett 251: 9-17.

Patel AK, Singh VK, Yadav RP, Moir AJG, Jagannadham MV 2009. ICChI, a glycosylated chitinase from the latex of Ipomoea carnea. Phytochem 70: 1210-1216.

Patel AK, Singh VK, Yadav RP, Moir AJG, Jagannadham MV 2010. Purification and characterization of a new chitinase from latex of Ipomoea carnea. Process Biochem. 45: 675-681.

Paula ACB, Hayashi LSS, Freitas JC 2003. Anti-inflammatory and antispasmodic activity of Ipomoea imperati (Vahl) Griseb (Convolvulaceae). Braz J Med Biol Res 36: 105112.

Paula-Zurron ACB, Petraglia NMMA, Aur CR, Moura SHP, Imamura PM., Freitas JC, Catanzaro-Guimarães AS 2010. Antinociceptive activity of Ipomoea imperati (Vahl) Griseb Convolvulaceae. Rev Bras Farmacogn 20: 180-185.

Pereda-Miranda R, Bah M 2003. Biodynamic constituents in the mexican morning glories: purgative remedies transcending boundaries. Curr Top Med Chem 3: 111131.

Pereda-Miranda R, Hernández-Carlos B 2002. HPLC Isolation and structural elucidation of diastereomeric niloyl ester tetrasaccharides from Mexican scammony root. Tetrahedron 58: 3145-3154.

Pereda-Miranda R 1995. Bioactive natural products from traditionally used Mexican plants. In: Arnason JT, Mata R, Romeo JT. Phytochemistry of medicinal plants. New York: Plenum Press, p. 83-112.

Pereda-Miranda R, Escalante-Sánchez E, Escobedo-Martínez C 2005. Characterization of lipophilic pentasaccharides from beach morning glory (Ipomoea pes-caprae). J Nat Prod 68: 226-230.

Pereda-Miranda R, Mata R, Anaya AL, Wickramaratne DBM, Pezzuto JM, Kinghorn AD 1993. Tricolorin A, major phytogrowth inhibitor from Ipomoea tricolor. J Nat Prod 56: $571-582$

Perusquia M, Mendoza S, Bye R, Linares E, Mata R 1995. Vasoactive effects of aqueous extracts from five Mexican medicinal plants on isolated rat aorta. $J$ Ethnopharmacol 46: 63-69.

Philpott M, Ferguson LR, Gould KS, Harris PJ 2009. Anthocyanidin-containing compounds occur in the periderm cell walls of the storage roots of sweet potato (Ipomoea batatas). J Plant Physiol 66: 1112-1117.

Pípole F, Latorre AO, Hueza IM 2010. Ipomoea carnea, a poisonous plant, promotes changes in lymphocyte distribution of young rats. Toxicol Lett 196: S200. 
Pongprayoon U, Bohlin L, Sandberg F, Wasuwat S 1989. Inhibitory effect of extract of Ipomoea pes-caprae on guinea-pig ileal smooth muscle. Acta pharm (Nordica) 1: 41-44.

Pongprayoon U, Bohlin L, Wasuwa S 1991a. Neutralization of toxic effects of different crude jellyfish venoms by an extract of Ipomoea pes-caprae (L.) R. Br. J Ethnopharmacol 35: 65-69.

Pongprayoon U, Baeckstrom P, Jacobsson U, Lindstrom M, Bohlin L 1991b. Compounds inhibiting prostaglandin synthesis isolated from Ipomoea pes-caprae. Planta Med 57: 515-518.

Pongprayoon U, Baeckstrom P, Jacobsson U, Lindstrom M, Bohlin L 1992a. Antispasmodic activity of ß-damascenona and E-phytol isolated from Ipomoea pes-caprae. Planta Med 58: 19-21.

Pongprayoon U, Baeckström P, Jacobsson U, Lindström M, Bohlin L 1992b. Inhibition of ethyl phenylpropiolateinduced rat ear oedema by compounds isolated from Ipomoea pes-caprae. Phytother Res 6: 104-107.

Prasad KN, Divakar S, Shivamurthy GR, Aradhya SM 2005a. Isolation of a free radical-scavenging antioxidant from water spinach (Ipomoea aquatica Forsk). J Sci Food Agric 85: 1461-1468.

Prasad KN, Ashok G, Raghu C, Shivamurthy GR, Vijayan P, Aradhya SM 2005b. In vitro cytotoxic properties of Ipomoea aquatica leaf. Indian J Pharmacol 37: 397398.

Rabah IO, Hou DX, Komine S, Fujii M 2004. Potential chemopreventive properties of extract from baked sweet potato (Ipomoea batatas Lam. Cv. Koganesengan). J Agric Food Chem 52: 7152-7157.

Rao CB, Suseela K, Rao PVS, Krishna PG, Raju GVS 1984. Chemical examination of some Indian medicinal plants. Indian J Chem 8: 787-788.

Rao KS, Rangan D, Singh K, Kaluwin C, Donals E, Rivett G, Jones P 1990. Lipid, fatty acid, amino acid and mineral composition of five edible plant leaves. J Agric Food Chem 38: 2137-2139.

Reynolds WF, Yu M, Enriquez RG, Gonzalez H, Leon I, Magos G, Villareal ML 1995. Isolation and characterization of cytotoxic and antibacterial tetrasaccharide glycosides from Ipomoea stans. J Nat Prod 58: 1730-1734.

Rogers KL, Grice ID, Griffiths LR 2000. Inhibition of platelet aggregation and 5-HT release by extracts of Australian plants used traditionally as headache treatments. Eur $J$ Pharm Sci 9: 355-363.

Runnie I, Salleh MN, Mohamed S, Head RJ, Abeywardena MY 2004. Vasorelaxation induced by common edible tropical plant extracts in isolated rat aorta and mesenteric vascular bed. J Ethnopharmacol 92: 311-316.

Saito N, Tatsuzawa F, Yoda K, Yokoi M, Kasahara K, Iida S, Shigihara A, Honda T 1995. Acylated cyanidin glycosides in the violet-blue flowers of Ipomoea purpurea. Phytochemistry 40: 1283-1289.

Saito N, Tatsuzawa F, Yokoi M, Kasahara K, Iida S, Shigihara A, Honda T 1996. Acylated pelargonidin glycosides in red-purple flowers of Ipomoea purpurea. Phytochemistry 43: $1365-1370$.

Saito N, Tatsuzawa F, Kasahara K, Iida S, Honda T 1998. Acylated cyanidin 3-sophorosides in the brownish-red flowers of
Ipomoea purpurea. Phytochemistry 49: 875-880.

Saito N, Toki K, Morita Y, Hoshino A, Lida S, Shigihara A, Honda T 2005. Acylated peonidin glycosides from duskish mutant flowers of Ipomoea nil. Phytochemistry 66: $1852-1860$.

Sarin JPS, Garg HS, Khanna NM, Dhar MM 1973. Ipolearoside: A new glycoside from Ipomoea leari with anti-cancer activity. Phytochemistry 12: 2461-2468.

Sattar EA, Gala A, Rashwan O 1995. Caffeoyl derivatives from the seeds of Ipomoea fistulosa. Int J Pharm 33: 155-158.

Schimming T, Tofern B, Mann P, Richter A, Jenett-Siems K, Dráger B, Asano N, Gupta MP, Correa MD, Eich E 1998. Distribution and taxonomic significance of calystegines in the Convolvulaceae. Phytochemistry 49: 1989-1995.

Schimming T, Jenett-Siems K, Mann P, Tofern-Reblin B, Milson J, Johnson RW, Deroin T, Austin DF, Eich E 2005a. Calystegines as chemotaxonomic markers in the Convolvulaceae. Phytochemistry 66: 469-480.

Schimming T, Jenett-Siems K, Siems K, Witte L, Eich E 2005b. N1, N10-ditigloylspermidine, a novel alkaloid from the seeds of Ipomoea nil. Pharmazie 60: 958-959.

Schwarz A, Hosomi RZ, Henrique BS, Hueza I, Gardner D, Haraguchi M, Górniak SL Bernardi MM, Spinosa HS 2004. Identificação de princípios ativos presentes na Ipomoea carnea brasileira. Rev Bras Cienc Farm 40: 181-187.

Shah CS, Qadry JS, Krishnamurthy TN 1972. Sugars and coumarins in Black-turpeth (Ipomea turpethum). Indian J Pharm 34: 126-127.

Sharda S, Kokate CK 1979. Indole alkaloids from the leaves of Ipomoea palmata Forsk. Indian Drugs 17: 70-71.

Shaw CY, Chen CH, Hsu CC, Chen CC, Tsai YC 2003. Antioxidant properties of scopoletin isolated from Sinomonium acutum. Phytother Res 17: 823-825.

Silva MSH 2002. Plantas com potencial terapêutico: elo integrador na promoção da saúde. I Congresso Brasileiro de Extensão Universitária. João Pessoa, Paraíba. http:// www.prac.ufpb.br/anais/Icbeu_anais/anais/saude/ plantas.pdf, acessed May 2011.

Sindambiwe JB, Calomme M, Cos P, Totté J, Pieters L, Vlietinck A, Berghe DV 1999. Screening of seven selected Rwandan medicinal plants for antimicrobial and antiviral activities. J Ethnopharmacol 65: 71-77.

Singh S, Stacey BE 1973. A new $\beta$-D-Quinovoside from comercial Ipomoea purga. Phytochemistry 12: 1701-1705.

Singh V, Pandey M, Srivastava A, Sethi R 2003. A non-ionic water-soluble seed gum from Ipomoea campanulata. Fitoterapia 74: 40-44.

Singh V, Srivastava V, Sethi R 2004. Ipomoea digitata seed gum and the gum-g-polyacrylamide: potential pharmaceutical gums. Pharm Biol 42: 230-233.

Smith Jr. CR, Niece LH, Zobel HF, Wolff IA 1964. Glycosidic constituents of Ipomoea parasitica seed. Phytochemistry 3: 289-299.

Son K, Severson RF, Arrendale RF, Kays SJ 1990. Isolation and characterization of pentacyclic triterpene ovipositional stimulant for the sweet potato weevil from Ipomoea batatas (L.) Lam. J Agric Food Chem 38: 134-137.

Souza MM, Madeira A, Berti C, Krogh R, Yunes RA, CechinelFilho V 2000. Antinociceptive properties of the methanolic extract obtained from Ipomoea pes-caprae 
(L.) R. Br. J Ethnopharmacol 69: 85-90.

Stanescu U, Riscalcic E, Grigorescu E 1973. Phytochemical study of Ipomoea violacea seeds. Farmacia (Bucharest, Romania) 21: 719-728.

Stange Jr RR, Midland SL, Holmes GJ, Sims JJ, Mayer RT 2001. Constituents from the periderm and outer cortex of Ipomoea batatas with antifungal activity against Rhizopus stolonifer. Postharvest Biol. Technol 23: 8592.

Steinegger E, Heimann H 1966. Pharmacochemistry and psychic effect of three Mexican wonder drugs. Gesellschaft in Bern 23: 83-99.

Suda I, Furuta S, Nishiba Y, Matsugano K, Sugita K 1997. Reduction of liver injury induced by carbon tetrachloride in rats administered purple-colored sweetpotato juice. Nippon Shokuhin Kagaku kogaku Kaishi (in Japanese) 44: 315-318.

Sun YL, Sun JM, Li QP 2009. Purification and trypsin inhibitor activity of a sporamin B from sweet potato (Ipomoea batatas Lam.). Agric Sci (China) 8: 808-820.

Taber WA, Vinig LC, Heacock RA 1963. Clavine and lysergic acid alkaloids in varieties of morning glory. Phytochemistry 2: 65-70.

Tan G, Xu P, Dai Z, Tang G 1995. Studies on the chemical components of Ipomoea batatas Lam. Tianran Chanwu Yanjiu Yu Haifa 7: 44-46.

Terahara N, Shimizu T, Kato Y, Nakamura M, Maitani T, Yamaguchi M, Goda Y 1999. Six diacylated anthocyanins from the storage roots of purple sweet potato, Ipomoea batatas. Biosci Biotechnol Biochem 63:1420-1424

Teramachi F, Koyano T, Kowithayakor T, Hayashi M, Komiyama $\mathrm{K}$, Ishibashi M 2005. Collagenase inhibitory quinic acid ester from Ipomoea pes-caprae. J Nat Prod 68: 794 796.

Tewati JP, Mishra SS 1965. Pharmacological investigations of Ipomoea digitata. Vijnana Parishad Anusandhan Patrika 7: 85-88.

Thomas TG, Rao S, Lal S 2004. Mosquito larvicidal properties of essential oil of an indigenous plant, Ipomoea cairica Linn. Jpn J Infect 57: 176-177.

Trute A, Gross J, Mutschler E, Nahrstedt A 1997. In vitro antispasmodic compounds of the dry extract obtained from Hedera helix. Planta Med 63: 125-129.

Tseng CF, Iwakami S, Mikajiri A, Shibuya M, Hanaoka F, Ebizuka Y, Padmawinata K, Sankawa U 1992. Inhibition of in vitro prostaglandin and leukotriene biosyntheses by cinnamoyl-beta-phenethylamine and $N$-acyldopamine derivatives. Chem Pharm Bull 40: 396-400.

Tseng CF, Mikajiri A, Shibuya M, Goda Y, Ebizuka Y, Padmawinata K, Sankawa U 1986. Effects of some phenolics on the prostaglandin synthesizing enzyme system. Chem Pharm Bull 34: 1380-1383.

Tsukui A, Kuwano K, Mitamura T 1983. Anthocyanin pigment isolated from purple root of sweet potato. Kaseigaku Zasshi 34: 153-159.

Uawonggul N, Chaveerach A, Thammasirirak S, Arkaravichien T, Chuachan C, Daduang S 2006. Screening of plants acting against Heterometrus laoticus scorpion venom activity on fibroblast cell lysis. J Ethnopharmacol 103: 201-207.
Umar S, Junior P, Wichtl M 1980. Isolation and identification of agroclavin and -dihydrolysergol from leaves of Ipomoea fistulosa. Planta Med 40: 328-332.

Wagner H 1973. The chemistry of the resin glycosides of the Convolvulaceae family, in: Bendz G, Santesson J (eds.), Medicine and Natural Sciences, Chemistry in Botanical Classification, Academic Press., New York, p. 235-240.

Wang LM, Chu YH 1996. Effect of norepinephrinergic system on ipalbidine analgesia. Acta Pharm Sinica 31: 806811.

Wasuwat S 1970. Extract of Ipomoea pes-caprae (Convolvulaceae) antagonistic to histamine and jellyfish poison. Nature 225: 758-59.

Weber JM, Ma TS 1976. Microchemical investigations of medicinal plants. XIV. Identification of the alkaloids in the leaves of Ipomoea violacea using preparative thin layer chromatography and solid probe mass spectrometry. Mikrochimica Acta 1: 227-242.

Wills RBH, Azhari R 1996. Determination of carotenoids in Chinese vegetables. Food Chem 56: 451-455.

Woradulayapinij W, Soonthornchareonnon N, Wiwat C 2005. In vitro HIV type 1 reverse transcriptase inhibitory activities of Thai medicinal plants and Canna indica L. rhizomes. J Ethnopharmacol 101: 84-89.

Yang C, Tsai T 1999. Four acylated anthocyanins from red skin sweet potatoes (Ipomoea batatas). Shipin Kexue (Tapei) 26: $182-192$

Yin YQ, Wang JS, Luo JG, Kong LY 2009. Novel acylated lipooligosaccharides from the tubers of Ipomoea batatas. Carbohydr Res 344: 466-473.

Yoshimoto M 2001. New trends of processing and use of sweetpotato in Japan. Farming Japan 35: 22-28.

Yoshimoto M, Okuno S, Yamaguchi M, Yamakawa O 2001. Antimutagenicity of deacylated anthocyanins in purplefleshed sweetpotato. Biosci Biotechnol Biochem 65: 1652-1655.

Yoshimoto M, Okuno S, Yoshinaga M, Yamakawa O, Yamaguchi M, Yamada J 1999. Antimutagenicity sweetpotato (Ipomoea batatas) roots. Biosci Biotechnol Biochem 63: 537-541.

Yoshimoto M, Yahara S, Okuno S, Islam MS, Ishiguro K, Yamakawa O 2002. Antimutagenicity of mono-, di-, and tricaffeoylquinic acid derivatives isolated from sweetpotato (Ipomoea batatas) leaf. Biosci Biotechnol Biochem 66: 2336-2341.

Ysrael MC 2003. Tonkin herbal drug: a multidisciplinary approach to development. Clin Hemorheol Micro 29: 247-251.

Yuan SQ, Zhao YM, You Y 2004. Alkaloids of the hairy roots of Ipomoea batatas Lam. Acta Pharm Sin 39: 818-20.

Zhao G, Kan J, Li Z, Chen Z 2005. Characterization and immunostimulatory activity of an $(1 \rightarrow 6)$-a-D-glucan from the root of Ipomoea batatas. Int Immunopharmacol 5: 1436-1445.

Zheng W, Clifford MN 2008. Profiling the chlorogenic acids of sweet potato (Ipomoea batatas) from China. Food Chem 106: 147-152.

Zhou J, Zhao G, Jin W, Zheng W, Chi Z 1988. Title. Chin Acad Sci Shanghai 9: 107-111. 


\section{*Correspondence}

Marilena Meira

Instituto de Química, Sala 218, Universidade Federal da Bahia,

Campus Universitário de Ondina

Rua Barão de Jeremoabo s/n, 40170-115 Salvador-BA, Brazil

marimeir@ufba.br

Tel: +55 7132836842 